\title{
Cytokine-induced neutrophil chemoattractant-1 is released by the noninjured liver in a rat acute-phase model
}

\author{
Nadeem Sheikh*, Kyrylo Tron*, Jozsef Dudas and Giuliano Ramadori \\ Department of Internal Medicine, Division of Gastroenterology and Endocrinology, University Hospital \\ Göttingen, Göttingen, Germany
}

\begin{abstract}
The source of serum cytokine-induced neutrophil chemoattractant (CINC-1) and consequences of its presence in the tissue of synthesis have not been clearly elucidated under acute-phase situation. To pursue this question, turpentine oil (TO) was intramuscularly injected into rats, and RNA and local protein levels of acutephase cytokines and of CINC-1 were studied in the TO injected gluteal muscle, as well as in noninjured muscle, in the liver, kidney, lung and spleen. The serum levels of acute-phase mediators and of CINC-1 were measured together with total leukocyte subpopulations. Recruitment of inflammatory cells in muscle and in the other organs was investigated by quantitative immunohistochemical methods. The effect of acute-phase mediators, including interferon gamma (IFN- $\gamma$ ) on the synthesis of CINC-1 in cultured hepatocytes was also investigated at the RNA and protein level. We found that the sera of the TO-treated rats contained elevated levels of IL-6, IL-1 $\beta$ and CINC-1. Increased serum levels of IFN- $\gamma$ were also observed not only in the injured muscle but also and to a higher extent in the liver. However, while neutrophils and mononuclear phagocytes were found in the injured muscle, no inflammatory cells were detected at the non-'inflamed' site, namely, the liver or in the other organs. In vitro, treatment of cultured hepatocytes with IL-1 $\beta$ led to elevated CINC-1 gene expression. This was true to a lesser extent upon IL-6 and tumor necrosis factor (TNF- $\alpha$ ) exposure. Interestingly, IFN- $\gamma$ did not effect CINC-1 gene expression. These results indicate that CINC-1 behaves as an acute-phase protein and its expression is inducible in hepatocytes. However, CINC-1-production in the liver does not lead to recruitment of inflammatory cells into the organ.
\end{abstract}

Laboratory Investigation (2006) 86, 800-814. doi:10.1038/labinvest.3700435; published online 22 May 2006

Keywords: CINC-1; acute-phase response; cytokines; liver; muscle; turpentine oil

Synthesis of chemokines in hepatocytes has been observed in the setting of inflammation of both acute and chronic liver diseases. ${ }^{1-6}$ Release of some chemokines from hepatocytes is considered to be responsible for recruitment of inflammatory cells. ${ }^{1,4,7-8}$ Conversely, several cytokines and growth factors have been shown to regulate chemokine gene expression in hepatocytes. ${ }^{4,9-13}$ Such cytokines (interleukins-(IL)- 1 and -6 , tumor necrosis factor- $\alpha$ (TNF- $\alpha$ ) and interferon- $\gamma$ ) are released during the acute-phase reaction. ${ }^{14-15}$ In such cases, increased serum levels of IL-8 (or in the rat, cytokine-induced neutrophil chemoattractant-1, CINC-1) have been

Correspondence: Dr G Ramadori, MD, DSc, Department of Internal Medicine, University Hospital Göttingen, Robert-KochStrasse 40, 37075 Göttingen, Germany.

E-mail: gramado@med.uni-goettingen.de

*These authors contributed equally to this work.

Received 9 February 2006; revised 23 March 2006; accepted 4 April 2006; published online 22 May 2006 observed..$^{2,4-6,14-22}$ Hence, the question can be raised as to whether specific cytokines induce or are induced by hepatic inflammation.

In a general sense, local injury and inflammation are accompanied by a systemic acute-phase response (APR), which is characterized by systemic leukocyte mobilization, fever, and changes in serum levels of glucocorticoids, cytokines, and liverderived acute-phase proteins (APPs). ${ }^{22}$ Increased IL-8 serum levels are associated with several inflammatory processes, including genitourinary infections (bacterial vaginosis and vaginitis), ${ }^{17}$ periodontitis, ${ }^{21}$ and iatrogenic situations as cardiopulmonary bypass ${ }^{18}$ and ischemia/reperfusion of the liver during liver transplantation. ${ }^{16}$

Inflammatory cells infiltrating the area of injury are known to be recruited from the blood by chemokine mediators released at the site of injury. ${ }^{23}$ In turn, inflammatory cells are responsible for production of cytokines, specifically, the major acute-phase (AP) mediators (IL-6, IL-1 $\beta$, TNF- $\alpha$ and 
interferon- $\gamma$ ), which are released into the blood ${ }^{24-27}$ and can act distantly on intact organs, predominantly on the liver. ${ }^{28}$ In the liver, AP-cytokines induce or increase the synthesis of many structural and secretory proteins, called positive APP. ${ }^{24-27}$ Synthesis of some other proteins (negative acutephase proteins) is decreased at the same time. ${ }^{15}$

In the rat, CINC- 1 is an $8-\mathrm{kDa}$ proinflammatory peptide and a member of the CXC family of chemokines, with potent chemotactic activity towards neutrophils. ${ }^{29,30}$ In addition to nonparenchymal cells such as Kupffer cells, liver parenchymal cells (hepatocytes) have been reported to produce CINC-1 in hepatic inflammatory processes..$^{8,12,31,32}$ CINC-1 protein is also released by the liver in response to different chemical injuring agents. ${ }^{33-35}$

CINC-1 is the rat homologue of the human growthregulated gene (GRO) of the IL-8 family. ${ }^{1,32,36}$ CINC-1 does not show any sequence similarity with human $I L-8$, but the function of CINC-1 closely resembles the human IL-8. ${ }^{1}$ Consequently, CINC- 1 is considered as a rat equivalent of IL-8 ${ }^{37}$

In this report, we utilized the model of a sterile abscess induced in skeletal muscle of the rat by injection of turpentine oil (TO) ${ }^{27,28,38-40}$ to study the expression of acute-phase cytokines and of CINC-1 at the injury site, and in noninjured muscle and in other organs including liver, lung, kidney and spleen. The serum levels of released mediators, including interferon-gamma (IFN- $\gamma$ ) and of CINC-1 were measured together with the tissue infiltration of total leukocytes as well as of neutrophils, monocytes and lymphocytes. Recruitment of inflammatory cells was quantified by morphometric methods. Tissue integrity was elucidated by histological and immunohistochemical methods, as well as by measurement of serum levels of marker enzymes. We also tested the effect of acute-phase mediators such as IFN- $\gamma$ on the synthesis of CINC-1 in cultured rat hepatocytes.

We found that CINC-1 is not only synthesized at the site of injury as it is for IL-6, IL-1 $\beta$, TNF- $\alpha$ and IFN- $\gamma$, but also, and even more importantly, in the liver. In the liver the major site of CINC-1 synthesis was the hepatocyte under the effect of the acutephase cytokines, mainly IL-1 $\beta$ and IL-6. CINC-1 synthesis alone seems not to be sufficient to induce recruitment of inflammatory cells into the liver; it also appears to be insufficient for other organs outside of the site of injury.

\section{Materials and methods}

\section{Animals}

Male Wistar rats (about $200 \mathrm{~g}$ body weight) were purchased from Harlan-Winkelmann (Borchen, Germany) and kept under standard conditions with 12$\mathrm{h}$ light/dark cycles and access to fresh water and food pellets ad libitum. All animals received humane care in accordance with the institution's guidelines, the German Convention for Protection of Animals and the National Institutes' of Health guidelines.

\section{Materials}

All chemicals were of analytical grade and obtained from commercial sources as indicated: pentobarbital sodium (Narcoren) from Merial (Hallbergmoos, Germany). TO was purchased from the University Pharmacy Goettingen (Goettingen, Germany). Media M199, collagenase type I and fetal calf serum were from Biochrom (Berlin, Germany). Nycodenz was obtained from Nyegaard (Oslo, Norway), agarose, guanidine isothiocyanate, Sybr Green Mix and Taq DNA-polymerase were from Invitrogen (Karlsruhe, Germany). L-glutamine was from PAA (Linz, Austria); cesium chloride from Paesel and Lorei (Frankfurt, Germany). All other reagents and chemicals were from Sigma-Aldrich Chemie (Munich, Germany) or Merck (Darmstadt, Germany).

\section{Antibodies}

Rabbit polyclonal antisera against human myeloperoxidase (MPO) and neutrophil elastase (NE) were purchased from DakoCytomation (Copenhagen, Denmark). Mouse anti-rat ectodysplasin-1 (ED1) monoclonal antibodies were from Serotec (Duesseldorf, Germany) and mouse monoclonal antibody against $\beta$-actin was obtained from SigmaAldrich Chemie. Horseradish peroxidase (HRP)conjugated anti-rabbit immunoglobulin from Amersham Pharmacia Biotech and rabbit anti-mouse-HRP or swine anti-rabbit-HRP immunoglobulins from DakoCytomation were used as secondary antibodies.

\section{Induction of Acute-Phase Reaction}

An acute-phase reaction was induced by injection of $5 \mathrm{ml} / \mathrm{kg}$ TO into the right $(0.5 \mathrm{ml})$ and left $(0.5 \mathrm{ml})$ hind limb gluteal muscles of ether-anesthetized rats; control animals received saline injection. Animals were killed at time points, ranging from $30 \mathrm{~min}$ to $48 \mathrm{~h}$ after TO administration under pentobarbital anesthesia. Hind limb muscle including the TOinjected area, noninjured hind limb muscle distant from the TO injected area, and noninjured fore limb muscle, were excised, as were liver and other organs. Tissues were rinsed with physiological saline, frozen in liquid nitrogen and stored at $-80^{\circ} \mathrm{C}$ until use. ${ }^{28}$

\section{Measurements of Blood Cell Counts and Serum Enzyme Levels}

At time points ranging from $30 \mathrm{~min}$ to $48 \mathrm{~h}$ after TO administration, blood samples from the inferior vena cava were collected from control and treated 
rats and were used for blood cell counts and serum analysis of enzyme activity measurements by standard routine diagnostic methods.

\section{Enzyme-Linked Immunosorbent Assay (ELISA)}

Blood samples were allowed to clot overnight at $4^{\circ} \mathrm{C}$ and centrifuged for $20 \mathrm{~min}$ at $2000 \mathrm{~g}$. Serum was removed and stored in aliquots at $-20^{\circ} \mathrm{C}$. Serum IL-6, IL-1 $\beta$, TNF- $\alpha$, IFN- $\gamma$ and CINC-1 were determined using specific ELISAs standardized with respective recombinant proteins (R\&D Systems, Wiesbaden, Germany), according to the manufacturer's instructions.

\section{Tissue Sections and Immunohistology}

For histology and immunohistochemistry, tissue specimens from injured and normal muscle, liver and other organs were rinsed with $0.9 \% \mathrm{NaCl}$ and snap-frozen in liquid nitrogen. Five micrometer cryostat sections were air-dried, fixed with methanol $\left(-20^{\circ} \mathrm{C}, 10 \mathrm{~min}\right)$ and acetone $\left(-20^{\circ} \mathrm{C}, 10 \mathrm{~s}\right)$, and stored at $-20^{\circ} \mathrm{C}$. After inhibition of endogenous peroxidase by incubating the slides with phosphate buffered saline (PBS) containing glucose/glucose oxidase/sodium azide, they were treated with FCS for $30 \mathrm{~min}$ to minimize nonspecific staining. The sections were incubated in a humidified chamber with the first antibody directed against NE, MPO and ED1 diluted in PBS at the ratio of 1:100 for $1 \mathrm{~h}$ at room temperature. Negative controls were incubated with normal mouse serum instead of the first antibody. After washing, the slides were covered with peroxidase-conjugated anti-mouse immunoglobulin preabsorbed with normal rat serum to avoid crossreactivity. Slides were washed and incubated with PBS containing 3,3'-diaminobenzidine $(0.5 \mathrm{mg} / \mathrm{ml})$ and $\mathrm{H}_{2} \mathrm{O}_{2}(0.01 \%)$ for $10 \mathrm{~min}$ to visualize immune complexes. Nuclei were counterstained with Meyer's hemalum solution before slides were mounted with coverslips.

\section{Quantitative Analysis of the Immunohistochemical Reactions}

Neutrophil elastase and ED1 positive cells were quantified in the inflamed muscle at the site of the TO injection, and also in the same tissue distant from the injection site. In the same animals, the fore limb muscle was used as 'non-injured muscle' and the above-mentioned reactions were quantified in other organs as well. In the liver, the periportal and pericentral areas were distinguished. The sampling was based on previously published methods. ${ }^{41}$ Images of immunohistochemical reaction were taken by an Axiovert $200 \mathrm{M}$ (Zeiss, Jena, Germany) microscope equipped by a high-resolution Axiocam camera. The scales of the taken images were calibrated using calibration specimens provided by Zeiss, in this regard, the surface area of positive reaction was compared to the whole surface of the taken image. The quantitative analysis was performed by the Axiovision software of Zeiss. Additionally, positive cells were counted in relation with the whole-cell number using ImageJ software (Wayne Rasband, NIH, USA). In all quantitative immunohistochemical analysis, 15 randomly obtained images from the investigated sections were analyzed at all examined time points and also functionally different areas (like periportal, pericentral liver, etc) were taken into consideration. The quantitative measurements in TO-treated animals at different time points were compared to salinetreated controls. In order to decide the statistical significance of the observed differences Student's $t$-test and one-way analysis of variance (ANOVA) were used.

\section{Preparation of Tissue Homogenates}

About $100 \mathrm{mg}$ of frozen tissue was homogenized with an Ultra-Turrax TP 18/10 three times for $10 \mathrm{~s}$ each in 10 volumes of $50 \mathrm{mM}$ Tris-HCl buffer, $\mathrm{pH}$ 7.4, containing $150 \mathrm{mM}$ sodium chloride, $1 \mathrm{mM}$ ethylenediaminetetraacetic acid, $1 \%$ Triton X-100, $1 \mathrm{mM}$ phenylmethanesulfonyl fluoride, $1 \mathrm{mM}$ benzamidine, $1 \mu \mathrm{g} / \mathrm{ml}$ leupeptin, $10 \mu \mathrm{M}$ chymostatin, $1 \mu \mathrm{g} / \mathrm{ml}$ antipain, $1 \mu \mathrm{g} / \mathrm{ml}$ pepstatin A. The entire procedure was carried out at $4^{\circ} \mathrm{C}$. Crude homogenates were passed five times through a $22 \mathrm{G}$ needle applied to a syringe, centrifuged for $5 \mathrm{~min}$ at $10000 \mathrm{~g}, 4^{\circ} \mathrm{C}$ and the protein concentration was determined in supernatants using the BCA protein assay reagent kit (Pierce, Bonn, Germany). Aliquots of the homogenates were stored at $-20^{\circ} \mathrm{C}$ until use. Tissue homogenates were used for CINC-1 specific ELISA.

\section{Isolation and Culture of Rat Liver Cells}

Hepatocytes were isolated from male Wistar rats by circulating perfusion with collagenase as described previously ${ }^{42,43}$ with slight modifications. ${ }^{4-47}$ Briefly, after anesthesia, the rat liver was perfused through the portal vein with $\mathrm{CO}_{2}$-enriched calcium-deprived Krebs-Ringer buffer $(120 \mathrm{mM} \mathrm{NaCl}, 4.83 \mathrm{mM} \mathrm{KCl}$, $1.2 \mathrm{mM} \quad \mathrm{MgSO}_{4} \cdot 7 \mathrm{H}_{2} \mathrm{O}, \quad 1.2 \mathrm{mM} \quad \mathrm{KH}_{2} \mathrm{PO}_{4}, 24 \mathrm{mM}$ $\mathrm{NaHCO}_{3}$ ) containing $0.25 \mathrm{mM}$ EDTA (pH 7.4), and then digested with perfusion solution $(\mathrm{pH}$ 7.4) containing Krebs-Ringer buffer, $0.05 \%$ collagenase, $4 \mathrm{mM}$ calcium chloride and $15 \mathrm{mM}$ HEPES for $7-$ $12 \mathrm{~min}$ at $37^{\circ} \mathrm{C}$ under recirculating conditions. The liver was excised, mechanically disrupted and rinsed in washing buffer ( $\mathrm{pH}$ 7.5) containing Krebs-Ringer buffer (without $\mathrm{NaHCO}_{3}$ ), $20 \mathrm{mM}$ HEPES and $0.4 \%$ BSA. Hepatocytes were then resuspended in the culture medium (M199 supplemented with $2 \mathrm{~g} / \mathrm{l} \mathrm{BSA}, 20 \mathrm{mM} \mathrm{NaHCO}_{3}, 10 \mathrm{mM}$ 
HEPES, $1 \mathrm{nM}$ insulin, $100 \mathrm{nM}$ dexamethasone, $100 \mathrm{U} / \mathrm{ml}$ penicillin and $100 \mu \mathrm{g} / \mathrm{ml}$ streptomycin), plated onto $60-\mathrm{mm}$ Falcon tissue culture dishes at a density $2 \times 10^{6}$ cells per dish and incubated at $37^{\circ} \mathrm{C}$ in humid atmosphere containing 95\% humidity and $5 \% \mathrm{CO}_{2}$. Fetal calf serum (5\%) was present during the plating phase up to $4 \mathrm{~h}$, afterward the cells were cultured under serum-free conditions. Kupffer cells were isolated from rat liver as described previously, ${ }^{48}$ plated to Falcon $1.5 \mathrm{~mm}$ tissue culture dishes, and used for experiments $24 \mathrm{~h}$ after plating.

\section{Isolation of Total RNA}

Total RNA was isolated from rat tissues by means of guanidine isothiocyanate extraction, cesium chloride density-gradient ultracentrifugation and ethanol precipitation, according to the method of Chirgwin, ${ }^{49}$ as described elsewhere. ${ }^{24}$ Alternatively, total RNA was isolated from cultured cells using the NucleoSpin ${ }^{\circledR}$ RNA II kit (Macherey-Nagel) with DNase treatment, ${ }^{50}$ according to the manufacturer's instructions. The RNA obtained was quantified by measuring the absorbance at $260 \mathrm{~nm}$ and used for reverse transcription with subsequent real time RT-PCR ${ }^{51}$ or subjected to Northern blot analysis. ${ }^{52}$

\section{Quantitative Real-Time RT-PCR, Northern Blot}

The cDNA was generated by reverse transcription of $1 \mu \mathrm{g}$ of total RNA with $100 \mathrm{nM}$ of dNTPs, $50 \mathrm{pM}$ of primer oligo $(\mathrm{dT})_{15}, 200 \mathrm{U}$ of moloney-murineleukemia virus reverse transcriptase (M-MLV RT), $16 \mathrm{U}$ of protector RNase inhibitor, $1 \times \mathrm{RT}$ buffer (Invitrogen) and $2.5 \mu \mathrm{l}$ of $0.1 \mathrm{M}$ DTT for $1 \mathrm{~h}$ at $40^{\circ} \mathrm{C}$. Expression of CINC-1, IL-6, IL-1 $\beta$, TNF- $\alpha$ and IFN- $\gamma$ was analyzed using Platinum sybr Green qPCR mix UDG. ${ }^{53} \beta$ Actin and Ubiquitine $\mathrm{C}$ were used as endogenous control. Primer sequences used are given in Table 1.

The amplification was performed at $95-60^{\circ} \mathrm{C}$ for 45 cycles in an ABI prism 7000 sequence detection system. ${ }^{54}$ All samples were assayed in duplicate. The results were normalized to the endogenous control and fold change expression was calculated using Ct values, and comparisons to experimental controls.
For Northern blot analysis total RNA was separated by agarose gel electrophoresis, transferred onto a nylon membrane and finally hybridized with specific $\alpha^{32}$ P-labelled dCTP labeled cDNA probes. Rat $C I N C-1$ cDNA probes were synthesized by using specific primers: forward: AATGAGCTGCGCTGT CAGT reverse: GGACACCCTTTAGCATCTTTTG (Probes were labeled with random priming Promega, Madison, WI, USA).

\section{Statistical Analysis}

Data are presented as means \pm s.e.m. The level of significance was set to $P<0.05$, statistical analysis was performed with Student's $t$-test and one-way ANOVA.

\section{Results}

\section{Assessment of Circulating Levels of Different Leukocyte Subpopulations, and Enzyme Serum Levels in TO-Treated Rats}

The circulating levels of total leukocytes, monocytes, neutrophils, and lymphocytes were analyzed throughout the 48-h time course. The number of circulating blood neutrophils rapidly increased reaching the maximum $4 \mathrm{~h}$ after TO injection, then fell below the basal levels at 36-48 h. The number of circulating monocytes in the blood of TO-treated rats exhibited a pattern of increases and decreases, but a clear pattern of change did not emerge (Figure 1a). The number of total leukocytes was decreased with increasing time interval after the treatment; the reduction was caused by the dropped levels of lymphocytes in the blood of TO-administrated rats (Figure 1b).

The serum level of creatine kinase (CK), the marker of muscle tissue damage, was highly elevated above control values as early as $30 \mathrm{~min}$ after administration of $\mathrm{TO}$, returning to below the baseline by $2 \mathrm{~h}$. A secondary peak at $24 \mathrm{~h}$ was observed (Figure 2a). The increase at the early timepoints was found to be statistically significant by Student's $t$-test $\left(P=1.77 \times 10^{-5}\right)$ analysis, and during the whole-time course by one-way ANOVA $\left(P<10^{-4}\right)$.

Serum activity of aspartate aminotransferase (AST) was found to be elevated $24 \mathrm{~h}$ after TO

Table 1 Primer sequences used for real time PCR analysis

\begin{tabular}{lll}
\hline Primer & Forward $5^{\prime}-3^{\prime}$ & Reverse $5^{\prime}-3^{\prime}$ \\
\hline CINC- 1 & CCC CCA TGG TTC AGA AGA TTG & TTG TCA GAA GCC AGC GTT CAC \\
IL- 6 & GTC AAC TCC ATC TGC CCT TCA G & GGC AGT GGC TGT CAA CAA CAT \\
IL- $\beta$ & TAC CTA TGT CTT GCC CGT GGA G & ATC ATC CCA CGA GTC ACA GAG G \\
TNF- $\alpha$ & ACA AGG CTG CCC CGA CTA T & CTC CTG GTA TGA AGT GGC AAA TC \\
IFN- $\gamma$ & AGTCTGAAGAACTATTTAACTCAAGTAGCAT & CTGGCTCTCAAGTATTTCGTGTTAC \\
$\beta$-actin & TGT CAC CAA CTG GGA CGA TA & AAC ACA GCC TGG ATG GCT AC \\
UBC & CAC CAA GAA GGT CAA ACA GGA A & AAG ACA CCT CCC CAT CAA ACC
\end{tabular}



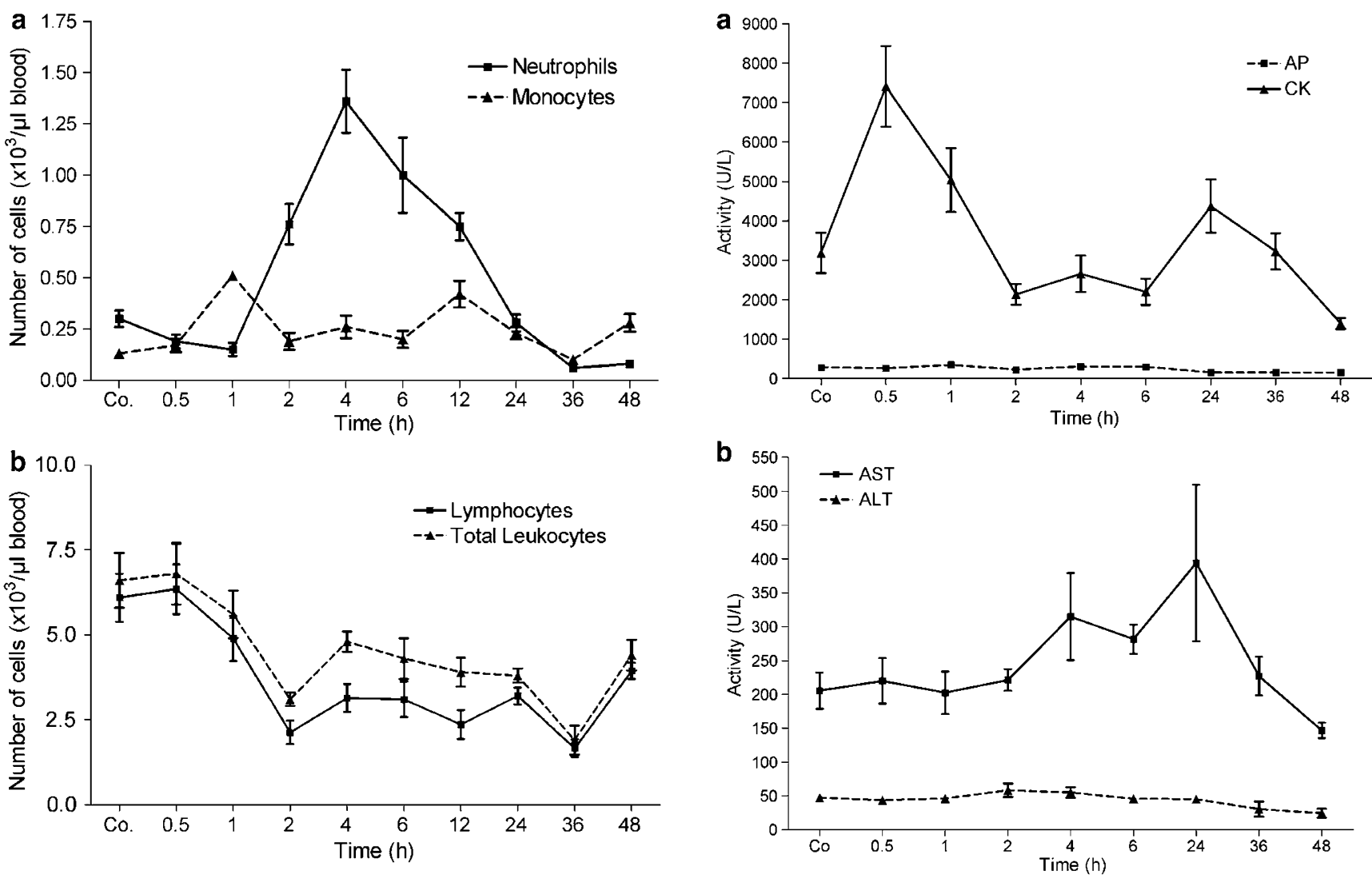

Figure 1 Blood cell counts in TO-treated rats. Circulating levels of neutrophils and monocytes (a), and lymphocytes and total leukocytes (b) were counted by standard diagnostic methods in the blood taken from rats throughout the 48-h time course after TO treatment. The number of circulating blood neutrophils rapidly increased, reaching the maximum $4 \mathrm{~h}$ after TO injection (a), while numbers of total leukocytes and lymphocytes were reduced with increased time interval after the treatment (b). The results are representative of three animal series (mean \pm s.e.m.).

administration, $\left(P<10^{-4}\right)$ (Figure 2b), while alanine aminotransferase (ALT, Figure 2b) and AP (Figure 2a) serum levels remained constantly normal during the experiment. Gamma-glutamyl transferase (GGT) activity remained undetectable in the serum at all time points (data not shown).

\section{Evaluation of the Serum Level of CINC-1 and of Acute-Phase Cytokines in TO-Treated Rats}

We found a highly significant increase of serum CINC-1 level $(P<0.001)$ from 2 to $24 \mathrm{~h}$ after the onset of acute-phase, with a maximum level at $6 \mathrm{~h}$, and reaching a 15-fold increase $(P<0.001$, with Student's $t$-test) above the control levels (Figure 3a). Statistically significant increases were found in the IL-6 serum concentration $(P<0.05)$ with a maximum at $6 \mathrm{~h}$ (12.5-fold increase), and in the IL- $1 \beta$ concentration at 6-12 h (three-fold increase, statistically significant, Figure $3 \mathrm{~b}$ ). IFN- $\gamma$ levels increased two-

fold above of the control $12 \mathrm{~h}$ after the TO-treatment, and TNF- $\alpha$ serum concentration was not changed (Figure 3c). The detectable increases of serum concentration of the measured cytokines and of CINC-1 occurred with the following kinetics: IL-1 $\beta$ (already increased $1 \mathrm{~h}$ after TO-administration), CINC-1; IL-6 (2 h), IFN- $\gamma$ (12 h).

\section{Tissue Damage and Leukocyte Recruitment was Found Only in the TO-Injured Muscle}

Despite the elevated levels of AST, usually considered as a potential marker of hepatocellular injury, hematoxylin-eosin staining of the liver sections from TO-treated rats did not reveal morphological changes indicating tissue damage within the observed period after TO-treatment (Figure 4). Similarly, hematoxylin-eosin staining in other organs like lung, kidney and spleen did not reveal morphological changes (see Supplementary material 

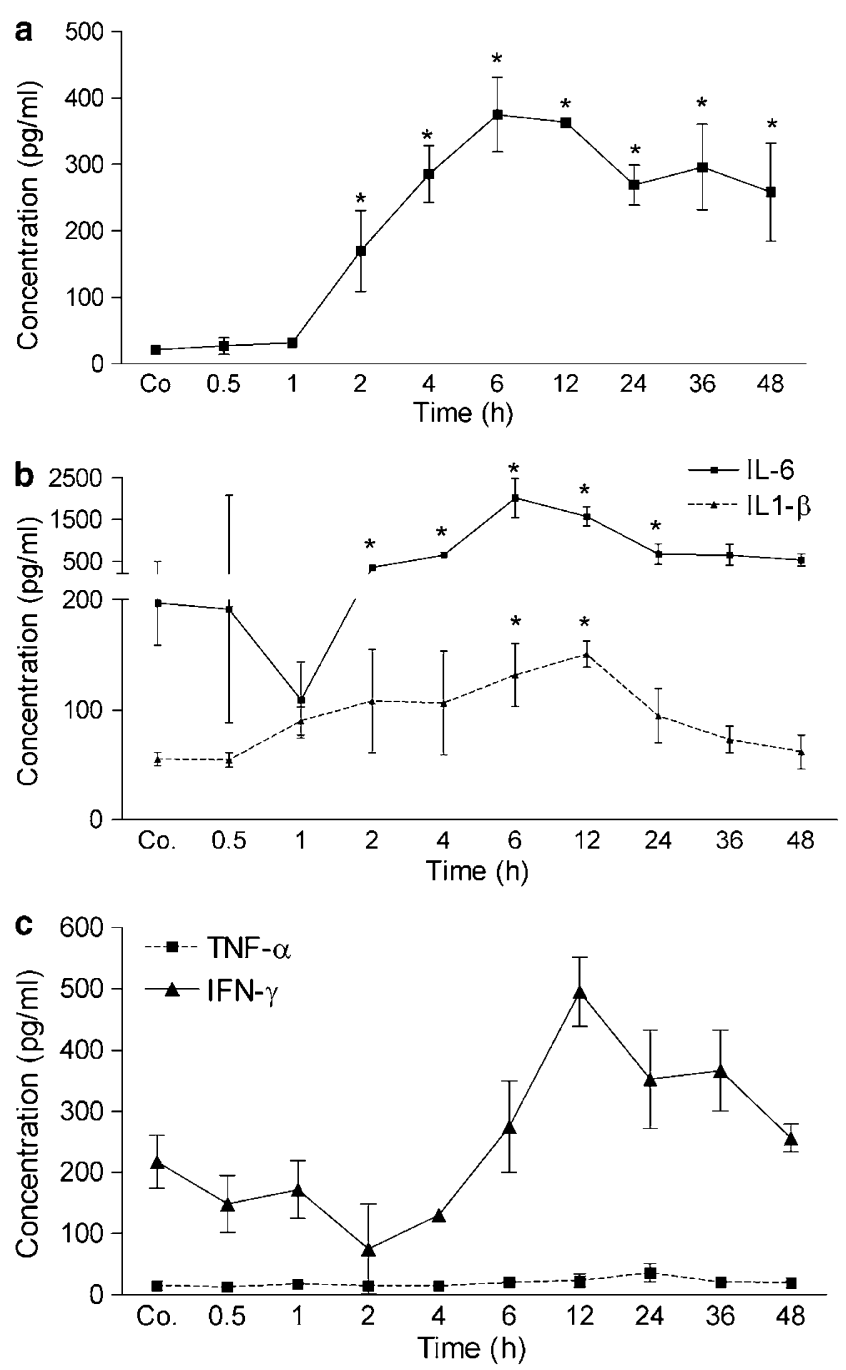

Figure 3 Serum concentrations of CINC-1 (a), IL-6 and IL1-1 $\beta$ (b); and TNF- $\alpha$ and IFN- $\gamma$ (c) throughout the 48-h time course after TO treatment. The serum levels of CINC-1, IL-6, IL1- $\beta$, TNF- $\alpha$ and IFN- $\gamma$ were measured in sera of TO-treated rats at indicated time points after intramuscular TO injection using respective specific ELISAs. Statistically significant changes $(P<0.05)$ are marked with asterisks. Results from three animals for each time point (mean \pm s.e.m.).

available on the journal web site). Immunohistochemical analysis using antibodies against neutrophil elastase (Figure 5a), ED1 (Figure 6a) and myeloperoxidase (Figure 6b) did not reveal any significant increase of the number of mononuclear phagocytes or neutrophil granulocytes in the livers of TO-treated rats compared to the livers of control rats. These observations were confirmed by quantitative analysis of the neutrophil elastase immunohistochemical reactions in the periportal and in the pericentral regions of the liver (Figure 5). The neutrophil elastase reaction remained at the control level at all time points after TO-injection both periportally and pericentrally $(P=0.16-0.43$, with one-way ANOVA and Student's $t$-test). Similar to the liver, in the lung, kidney and spleen of TO-treated rats, no significant change of neutrophil elastase reaction was observed at any time points after TOinjection $(P=0.16-0.56$, with one-way ANOVA and Student's $t$-test) (Figure $5 \mathrm{~d}$ and Supplementary material).

Likewise, the number of ED1 positive cells was also not increased in the liver at any time points after TO-treatment (Figure 6c) $(P=0.1-0.48$, with one-way ANOVA and Student's $t$-test).

In contrast, in the injured muscle, at the site of TO-injection significant morphological changes were observed, including the increase of inflammatory cell density among the muscle fibres (Figure $4 \mathrm{~b})$, which was most prominent $24 \mathrm{~h}$ after the TOinjection. The recruitment of neutrophil-elastasepositive-cells was already significant $2 \mathrm{~h}$ after TO injection (Figure 5c; $P=0.017$ with Student's $t$-test compared to saline-treated control), reaching its maximum $24 \mathrm{~h}$ after TO injection. At all time points after TO-treatment, the neutrophil elastase immunohistochemical reaction was significantly higher in the injured muscle than in the saline-treated controls, and in the non-injured fore limb muscles $\left(P=3 \times 10^{-4}-0.02\right.$, with one-way ANOVA and Student's $t$-test).

Similarly, ED1 positive cells were recruited to the site of injury, maximally at $24 \mathrm{~h}$ after TO-injection. As demonstrated in Figure 6e, the ED1-positive reaction was significantly lower at $400 \mu \mathrm{m}$ from the site of injection $(P=0.013$ with Student's $t$-test). At $24 \mathrm{~h}$ after TO-injection, the recruitment of ED1-positive cells to the site of injury and also $400 \mu \mathrm{m}$ further from it, reached statistical significance $\left(P=10^{-4}\right.$ at the site of the injection, and $P=10^{-3} 400 \mu \mathrm{m}$ from it; with Student's $t$-test compared with saline-treated controls). In the noninjured fore limb muscles of the TO-treated rats, no change of the number of ED1 ${ }^{+}$cells was found (Figure 6c).

\section{Expression of CINC-1 mRNAs and Protein, and mRNA Expression of Acute Phase Cytokines in Injured Muscle and Liver of TO-Treated Rats}

Intramuscular injection of TO led to a local inflammation and injury of the muscle followed by generalized APR, as previously described. ${ }^{28}$ As revealed by real-time RT-PCR, CINC-1 mRNA was induced not only in the injured muscle at the site of TO-injection but also and even to a higher extent in the liver (Table 2a; shown graphically in Figure 7a). The upregulation of CINC-1 mRNA was observed in the injured muscle and in the liver already $2 \mathrm{~h}$ after TO injection. The maximum induction of CINC-1 mRNA occurred at 4-6 h after TO injection (about 40 -fold in the muscle and more than 260 -fold in the liver when compared to values at $t=0 \mathrm{~h}$ ). The same induction pattern was detectable at protein level using tissue lysates (Table 2a, Figure 7b). CINC-1 

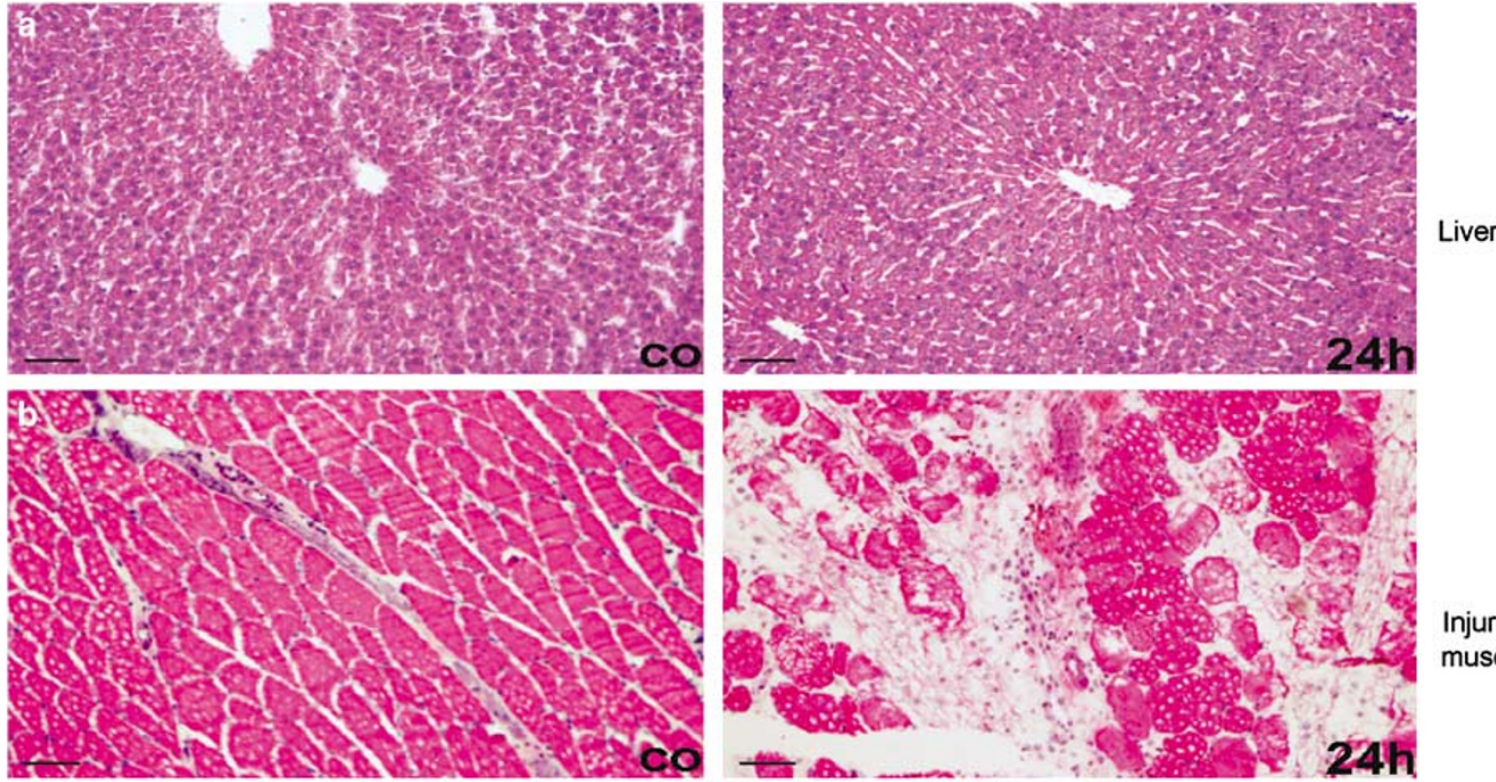

Injured

muscle
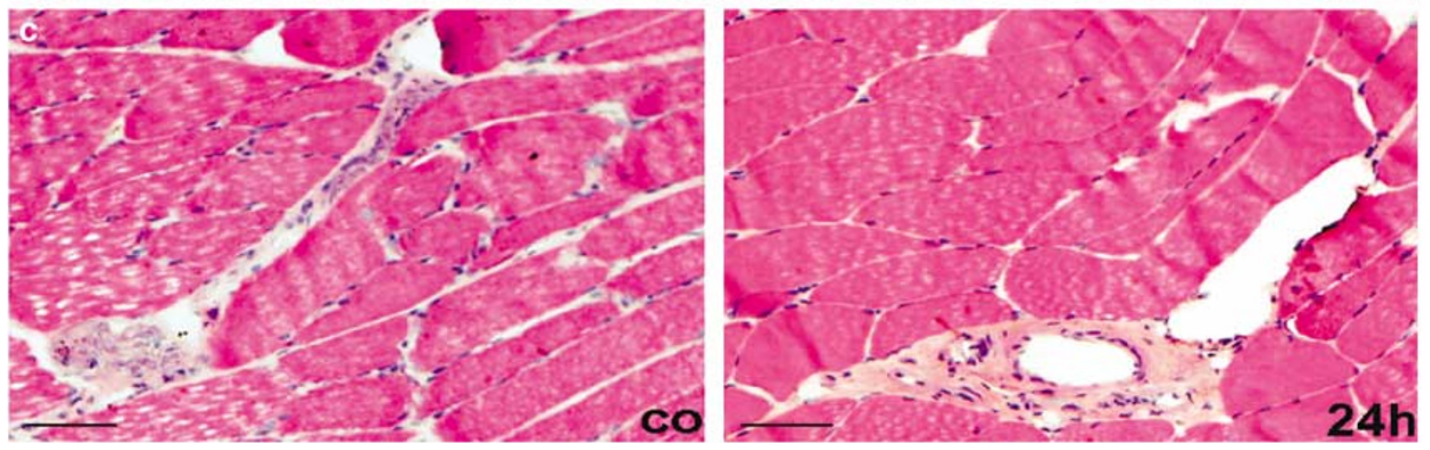

Non-injured

muscle

Figure 4 Hematoxylin-eosin stainings of liver (a) and muscle (b, c) of saline-treated (control; co) and TO-treated rats (24h after TO-injection). The liver did not show morphological alterations during the course of the observed $48 \mathrm{~h}$ after TO-treatment, while the muscle, which was the site of the TO injection, showed destruction of the fiber structure and recruitment of inflammatory cells peaking $24 \mathrm{~h}$ after the injection. Magnification: $(\mathbf{a}, \mathbf{b}) \times 100$, (c) $\times 200$, bars $=100 \mu \mathrm{m}$.

concentration per mg of wet tissue increased in the liver $2 \mathrm{~h}$ after TO injection and it was 5.66 -fold higher than in the injured muscle. This increase was associated with an increase of CINC-1-protein level in the serum (Figure 3a).

As revealed by real time RT-PCR analysis, mRNA level of IL1- $\beta$ and TNF- $\alpha$ were significantly elevated in the liver, reaching their maximums $4-6 \mathrm{~h}$ after TO administration, about four- and three-fold respectively, whereas IL-6 was not upregulated (Table $2 \mathrm{~b}$, Figure 7c). However, in the injured muscle, IL-6 mRNA levels were significantly upregulated up to 2000 -fold 4-6 h after the treatment with TO. ${ }^{28}$ At the same time, IL-1 $\beta$ mRNA was induced to about 425fold, whereas statistically nonsignificant changes in TNF- $\alpha$ mRNA levels were observed (Figure $7 d$ ).

In summary, CINC-1 gene expression in the liver was upregulated $2 \mathrm{~h}$ after the intramuscular TOinjection, and reached the maximum $6 \mathrm{~h}$ after the TO-injection. Hepatic $I L-1 \beta$ and $T N F-\alpha$ but not $I L-6$ gene expression were upregulated, reaching their maxima $6 \mathrm{~h}$ after the TO-injection. In the injured muscle after TO-treatment, CINC-1 was similarly upregulated as in the liver, but to a lower extent, and reached a maximum $6 \mathrm{~h}$ after the TO injection. IL1- $\beta$ and $T N F-\alpha$ were upregulated to a higher extent than in the liver, reaching their maximum $6 \mathrm{~h}$ after the TO injection, and $I L-6$ was about 2000-fold upregulated.

In the serum of TO-treated animals, highly elevated IL-6 and elevated IL-1 $\beta$ levels were found (Figure 3b), with similar kinetics as their mRNA expressions in the injured muscle. Interestingly, the early increase of IL- $1 \beta$-serum levels $(1 \mathrm{~h})$ was correlated more with the increase of mRNA expression in the liver $(1 \mathrm{~h})$ than in the injured muscle (Figures 3b, 7c, and d).

\section{CINC-1 expression in vitro}

Primary cultured rat hepatocytes and Kupffer cells were treated with increasing doses of acute-phase cytokines (IL1- $\beta$, IL- 6 and TNF $\alpha$ ), and CINC-1 mRNA was detected by real-time RT-PCR and Northern blots. By RT-PCR (Figure 8a), CINC-1 mRNA levels in hepatocytes reached 18.0 and 13.5 fold induction, 
a
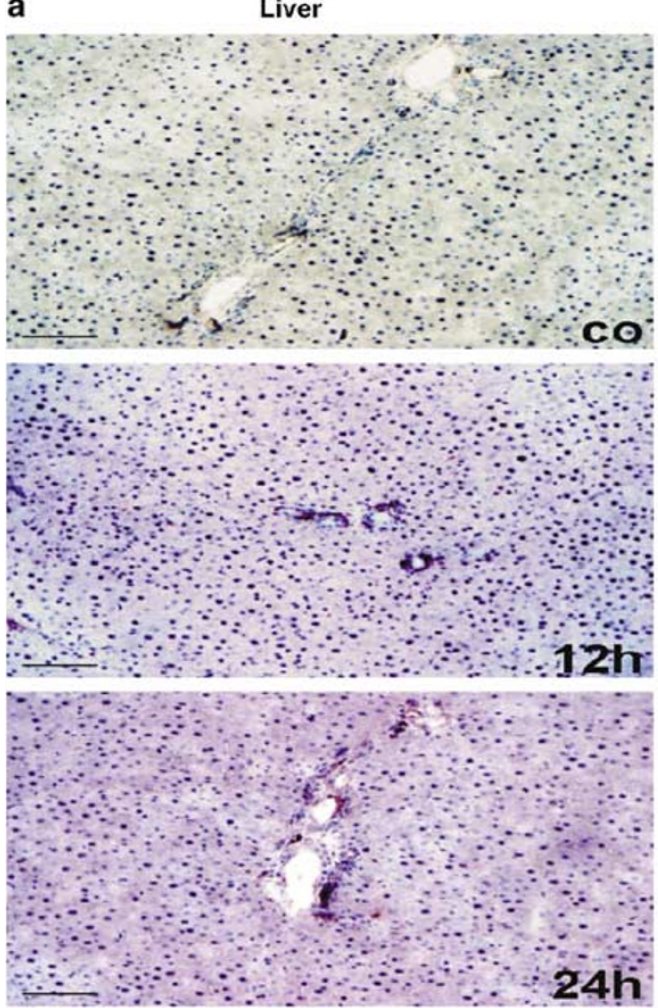

b
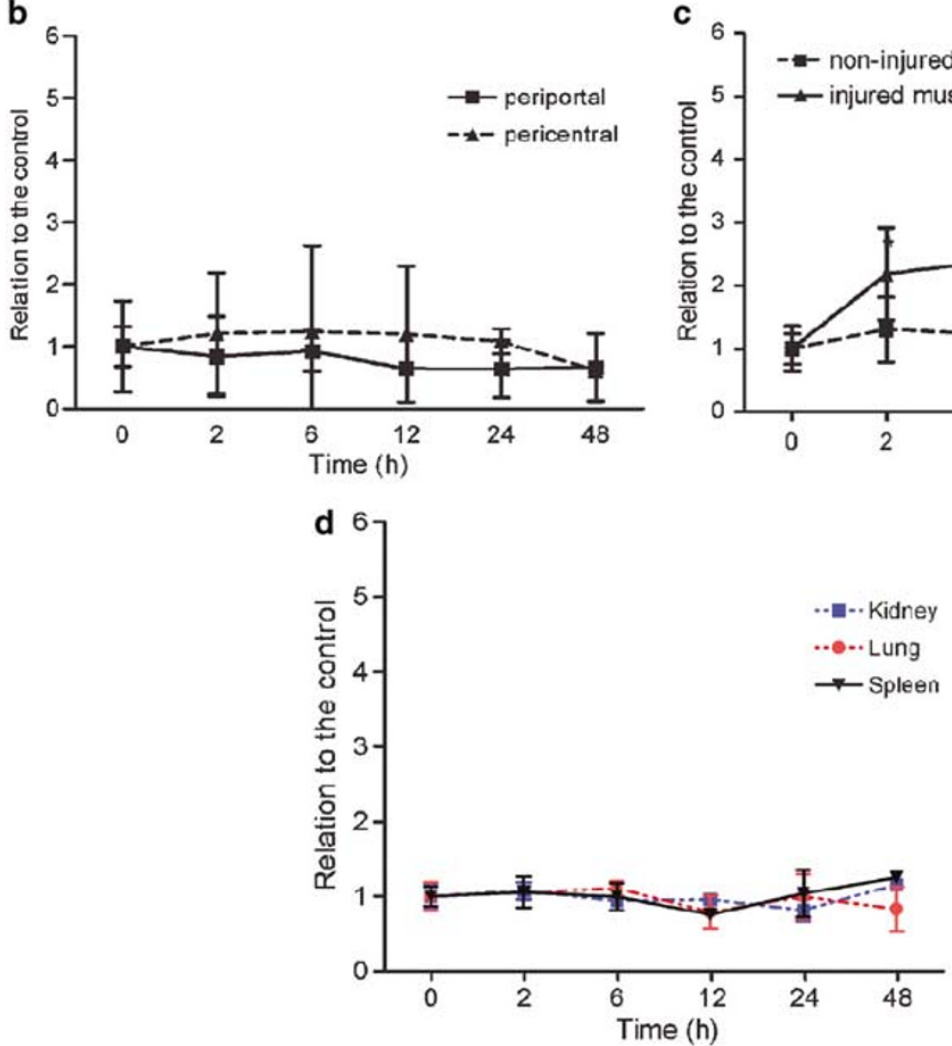

Injured muscle
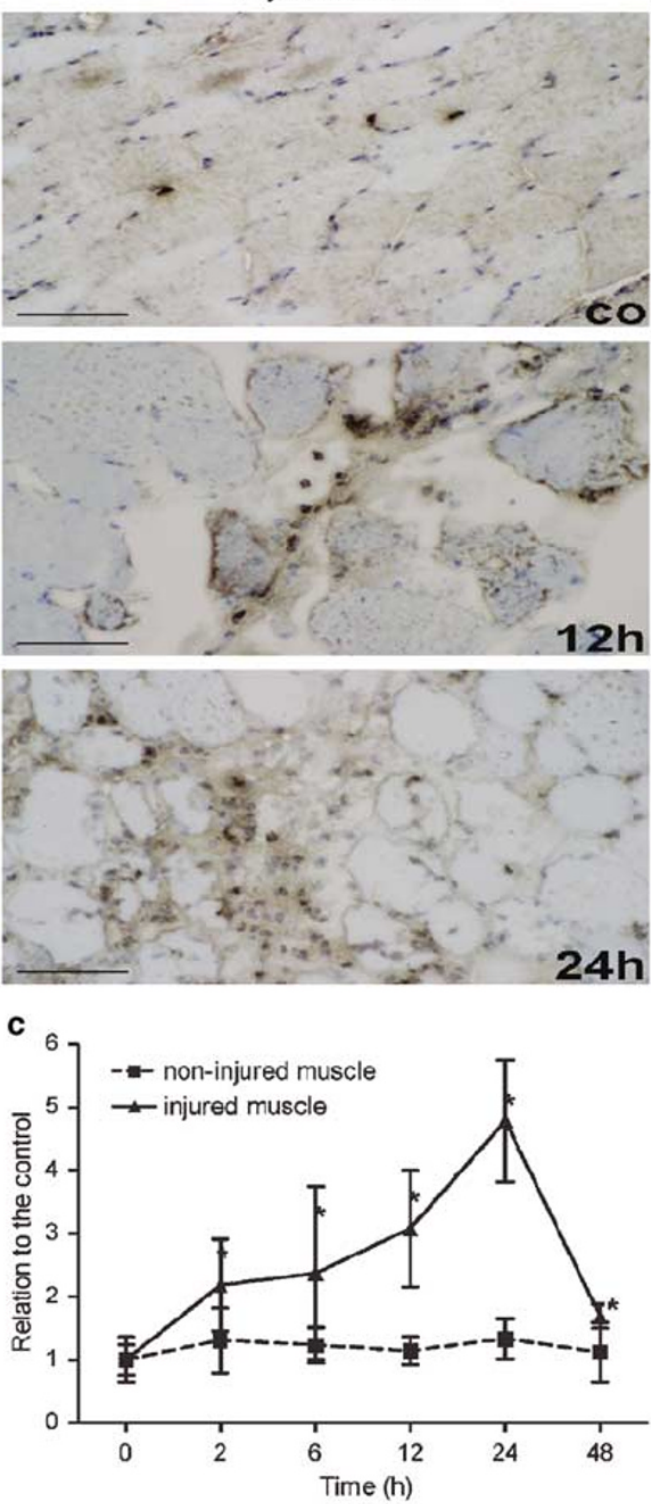

Figure 5 (a) Immunohistochemistry for NE in the livers and muscles of control (saline-treated rats) and in TO-treated rats 12 and $24 \mathrm{~h}$ after TO injections. In the liver, no recruitment of immunoreactive cells was observed. In injured muscle, neutrophil-elastase positive cells accumulated over the 12-24 h sampling period. (b) Quantitative analysis of NE-positive cells in periportal and pericentral areas of livers of TO-treated rats, relative to saline-treated controls. (c) Quantitative analysis of NE-positive cells in injured hind limb muscles and in noninjured fore limb muscles of TO-treated rats relative to saline-treated controls. (d) Quantitative analysis of NE positive cells in lung, kidney and spleen of TO-treated rats related to saline-treated controls. Magnification: liver, $\times 100$; muscle, $\times 200$, bars $=100 \mu \mathrm{m})$. ${ }^{*} P<0.05$. 

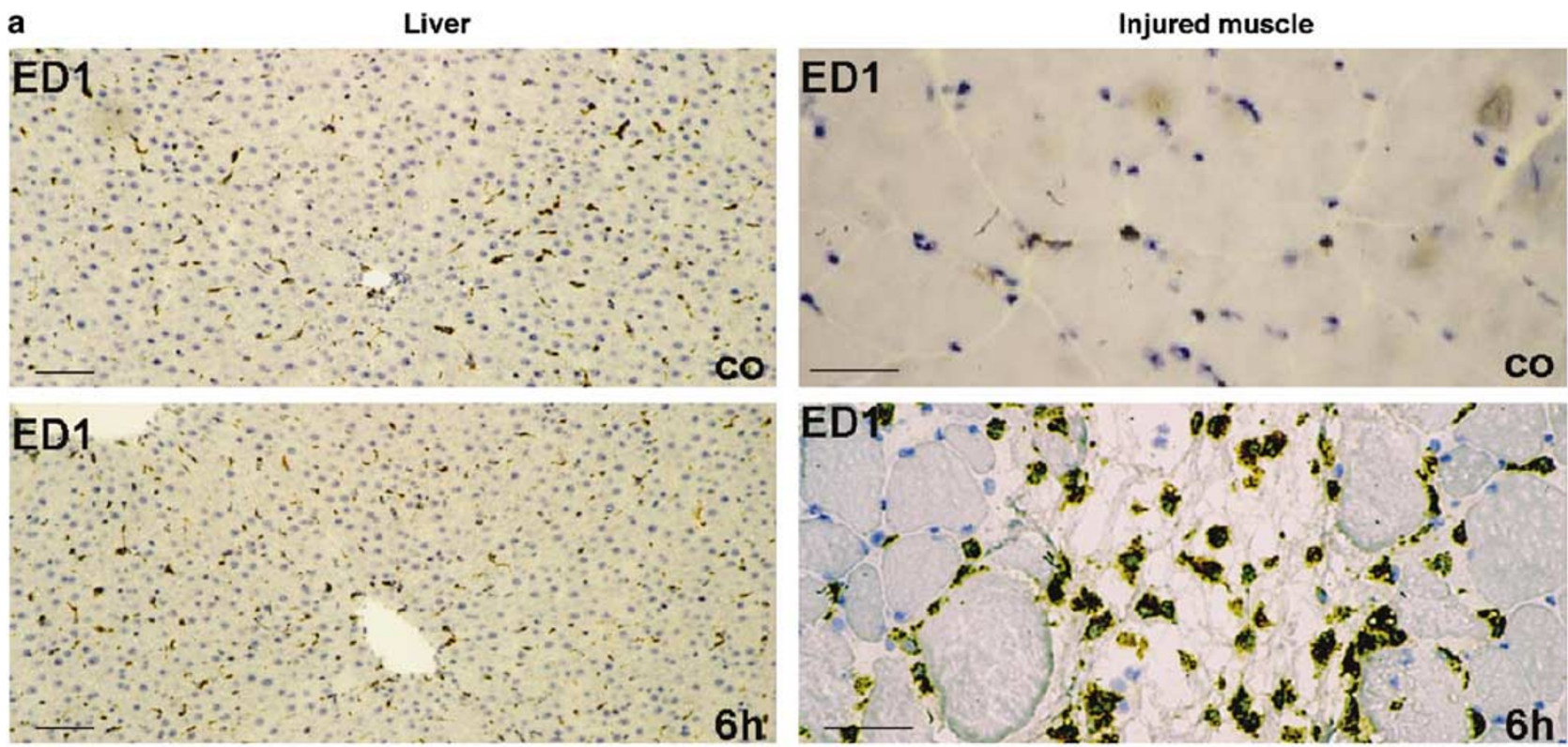

b
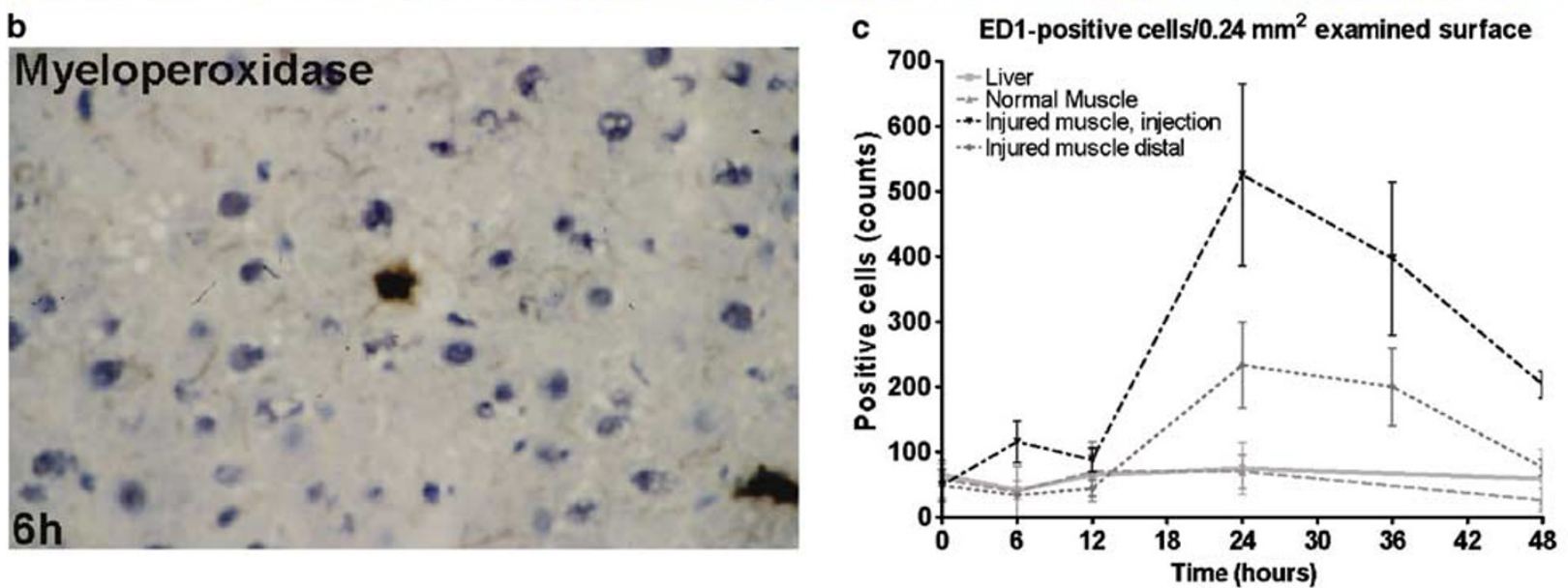

Figure 6 ED1 immunohistochemisty of liver and muscle of (a) control rats and of TO-treated rats $6 \mathrm{~h}$ after TO injection; (b) Myeloperoxidase staining in the liver $6 \mathrm{~h}$ after TO injection. No infiltration of polymorphic nuclear cells (as indicated by no increase in ED-1 or myeloperoxidase immunreactivity) was observed in the liver, whereas ED-1-positive cells did accumulate in injured muscle. Magnification: (a) liver, $\times 100$; muscle, $\times 200$; (b) $\times 200$, bars $=100 \mu \mathrm{m}$. (c) Quantitative analysis of ectodysplasin-1 (ED-1) positive cells related to $0.24 \mathrm{~mm}^{2}$ examined tissue surface in the liver, injured muscle at the site of injection, and $400 \mu \mathrm{m}$ away from it, and in noninjured fore limb muscle of TO-treated rats related to saline-treated controls (mean \pm s.e.m.).

compared to untreated controls, upon exposure to maximal doses of IL1- $\beta$ and IL-6 (1000 ng/ml), respectively. In contrast, TNF- $\alpha$ at the same doses was only able to induce CINC-1 mRNA expression in primary hepatocytes about two-fold compared to control levels. It is worth noting that all acutephase cytokines induced a rapid increase of CINC-1 mRNA expression, which was apparent 20 min after the beginning of the treatment (not shown). The differences in mRNA expression were clearly detectable by Northern blot analysis as well (Figure $8 b$, c and d).

Given that serum levels of IFN- $\gamma$ did not increase after TO-injection of muscle (Figure 3c) nor did mRNA levels of INF- $\gamma$ in injured muscle (Figure $7 \mathrm{~d}$ ), we evaluated whether IFN- $\gamma$ had any synergistic effect on the actions of other acutephase cytokines. TNF- $\alpha$, IL1- $\beta$ and IL-6 applied separately to isolated hepatocytes in culture all induced CINC-1 mRNA expression, as detected by real-time RT-PCR (Figure 9a) and Northern blots (Figure 9c,d). IFN- $\gamma$ alone did not induce significant changes in the CINC-1-gene expression (Figure 9a). Likewise, IFN- $\gamma$ applied in combination with IL1- $\beta$, IL-6 or TNF- $\alpha$ had no additional effect (Figure 9b). The mRNA expression patterns in hepatocytes after cytokine treatments were followed by a similar protein release pattern measured by ELISA in the supernatants of the treated cells (Figure 9e).

In isolated rat Kupffer cells the CINC-1 expression was 24.2-fold higher than in the isolated hepato- 
Table 2a Rapid increase of CINC-1 mRNA (fold change compared to control) and protein (pg/mg total protein) expression in liver and injured muscle after TO-treatment

\begin{tabular}{|c|c|c|c|c|}
\hline & \multicolumn{2}{|c|}{ CINC-1 mRNA expression fold change related to control rats } & \multicolumn{2}{|c|}{ CINC-1 protein expression (pg/mg total protein) } \\
\hline & Liver & Injured muscle & Liver & Injured muscle \\
\hline Time (h) & $\bar{X} \pm$ s.e.m. & $\bar{X} \pm$ s.e.m. & $\bar{X} \pm$ s.e.m. & $\bar{X} \pm$ s.e.m. \\
\hline 0 & $1.0 \pm 0.4$ & $1 \pm 0.3$ & $4.3 \pm 1.4$ & $0.9 \pm 0.9$ \\
\hline 0.5 & $0.8 \pm 0.1$ & $0.5 \pm 0.0$ & $5.2 \pm 1.5$ & $1.5 \pm 0.4$ \\
\hline 1 & $1.2 \pm 0.1$ & $0.1 \pm 0.0$ & $4.9 \pm 0.4$ & $1.6 \pm 0.7$ \\
\hline 2 & $109 \pm 3$ & $3.1 \pm 0.2$ & $11.8 \pm 3.7$ & $2.1 \pm 0.5$ \\
\hline 4 & $232 \pm 32$ & $25.7 \pm 1.5$ & $12.6 \pm 2.1$ & $5.1 \pm 0.4$ \\
\hline 6 & $259 \pm 30$ & $39 \pm 2.4$ & $11.6 \pm 3.0$ & $5.0 \pm 0.5$ \\
\hline 12 & $118 \pm 14$ & $4.9 \pm 1.3$ & & \\
\hline 24 & $32 \pm 10$ & $1.5 \pm 1.1$ & & \\
\hline 36 & $43 \pm 19$ & $2.2 \pm 0.1$ & & \\
\hline 48 & $34 \pm 17$ & $3.5 \pm 0.2$ & & \\
\hline
\end{tabular}

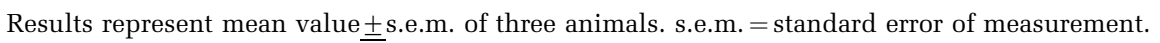

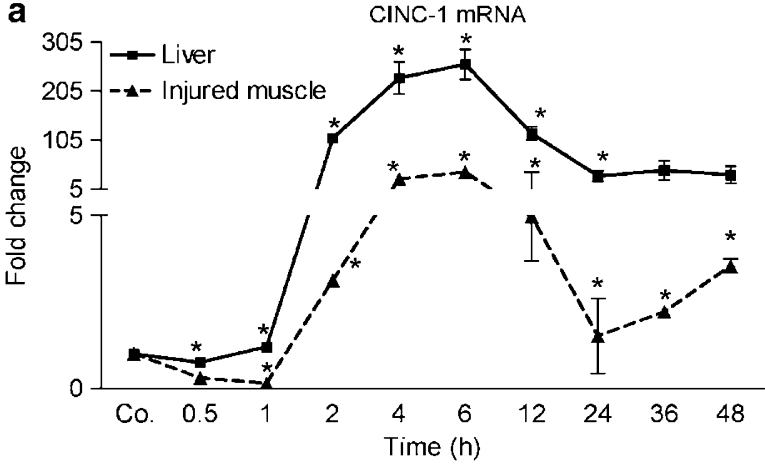

C

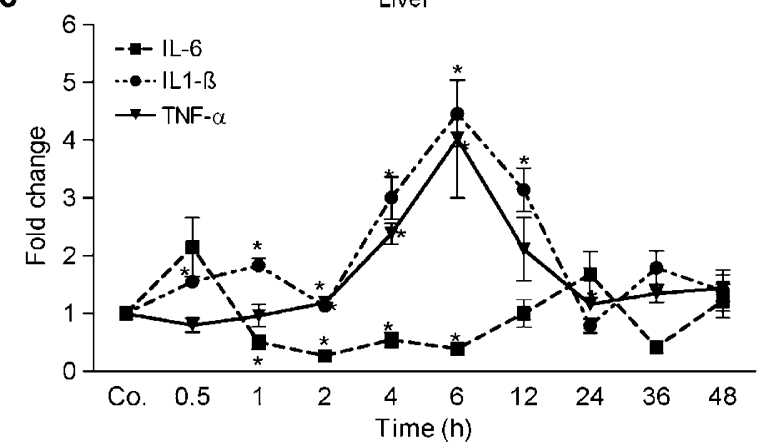

b

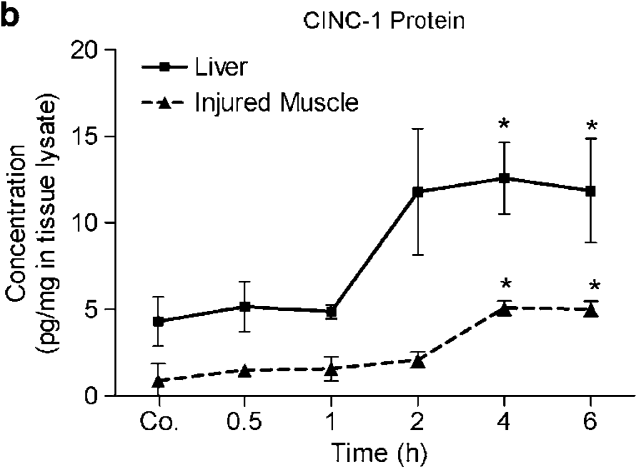

d

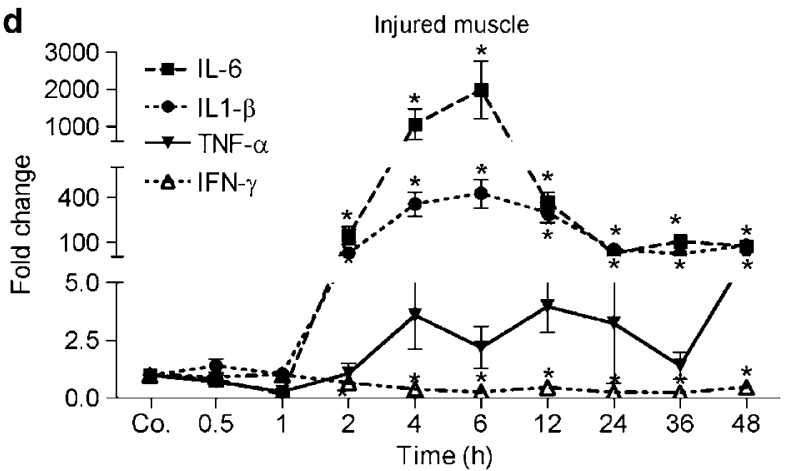

Figure 7 Expression of CINC-1 mRNA (a) and protein (b) in liver and injured muscle, and mRNA of acute-phase cytokines in liver (c) and injured muscle (d) at different time points after intramuscular TO treatment. The mRNA expression was quantified by real-time RT-PCR (a, c and d), CINC-1 protein was quantified by ELISA in lysates of liver and injured muscle (b). The CINC-1 concentrations were related to the total protein of the lysates, based on total protein concentration measurements (b). CINC-1 protein was induced in liver $2 \mathrm{~h}$ after TO injection, while at the site of TO injection the induction occurred only $4 \mathrm{~h}$ after the TO injection. Results represent mean value \pm s.e.m. of three animals. ${ }^{*} P<0.05$.

cytes (Table 3). Interestingly, in the serum of TOtreated rats, the IL-6 was the highest induced cytokine. Although it stimulated the CINC-1 expression in isolated rat hepatocytes, IL-6 did not have a stimulatory effect on Kupffer cells (Ct-values did not change, Table 3).

\section{Discussion}

The results of the current study demonstrate that after intramuscular TO-injection CINC-1 serum levels become elevated. This elevation is preceded by increases of the serum concentrations of IL-6 and 
Table 2b Comparison of the mRNA expression of IL-6, IL1- $\beta$ and TNF- $\alpha$ in liver and injured muscle after TO treatment (fold change compared to control)

\begin{tabular}{|c|c|c|c|c|c|c|}
\hline & \multicolumn{2}{|c|}{ IL-6 mRNA expression } & \multicolumn{2}{|c|}{ IL-1 $\beta$ mRNA expression } & \multicolumn{2}{|c|}{$T N F-\alpha$ mRNA expression } \\
\hline & Liver & Injured muscle & Liver & Injured muscle & Liver & Injured muscle \\
\hline Time (h) & $\bar{X} \pm$ s.e.m. & $\bar{X} \pm$ s.e.m. & $\bar{X} \pm$ s.e.m. & $\bar{X} \pm$ s.e.m. & $\bar{X} \pm$ s.e.m. & $\bar{X} \pm$ s.e.m. \\
\hline Co. & $1.0 \pm 0.3$ & $1.0 \pm 0.1$ & $1.0 \pm 0.0$ & $1.0 \pm 0.0$ & $1.0 \pm 0.1$ & $1.0 \pm 0.0$ \\
\hline 0.5 & $2.2 \pm 0.5$ & $0.8 \pm 0.3$ & $1.6 \pm 0.1$ & $1.4 \pm 0.3$ & $0.8 \pm 0.1$ & $0.7 \pm 0.3$ \\
\hline 1 & $0.5 \pm 0.1$ & $0.2 \pm 0.1$ & $1.8 \pm 0.1$ & $1.1 \pm 0.2$ & $1.0 \pm 0.2$ & $0.3 \pm 0.1$ \\
\hline 2 & $0.3 \pm 0.1$ & $147 \pm 58$ & $1.1 \pm 0.0$ & $28 \pm 6$ & $1.2 \pm 0.0$ & $1.1 \pm 0.4$ \\
\hline 4 & $0.5 \pm 0.1$ & $1055 \pm 414$ & $3.0 \pm 0.4$ & $355 \pm 80$ & $2.4 \pm 0.2$ & $3.6 \pm 1.5$ \\
\hline 6 & $0.4 \pm 0.1$ & $1982 \pm 777$ & $4.5 \pm 0.6$ & $425 \pm 95$ & $4.0 \pm 1.0$ & $2.2 \pm 0.9$ \\
\hline 12 & $1.0 \pm 0.2$ & $371 \pm 61$ & $3.1 \pm 0.4$ & $299 \pm 67$ & $2.1 \pm 0.6$ & $4.0 \pm 1.1$ \\
\hline 24 & $1.7 \pm 0.4$ & $27 \pm 19$ & $0.8 \pm 0.1$ & $53 \pm 12$ & $1.2 \pm 0.0$ & $3.2 \pm 2.6$ \\
\hline 36 & $0.4 \pm 0.1$ & $109 \pm 43$ & $1.8 \pm 0.3$ & $23 \pm 5$ & $1.4 \pm 0.2$ & $1.4 \pm 0.6$ \\
\hline 48 & $1.2 \pm 0.3$ & $75 \pm 30$ & $1.4 \pm 0.4$ & $80 \pm 18$ & $1.4 \pm 0.2$ & $7.3 \pm 3.0$ \\
\hline
\end{tabular}

The mRNA expression is related to controls. Results represent mean value \pm s.e.m. of three animals. s.e.m. $=$ standard error of measurement.

IL-1 $\beta$. CINC-1 mRNA and protein levels increased in the liver with the same time course as in the serum. In isolated rat liver hepatocytes, CINC-1-gene-expression could be upregulated by IL- $1 \beta$ and IL-6, while Kupffer cells showed a constitutive CINC-1expression, higher than that of hepatocytes, which could not be further upregulated. These data suggest that the hepatocyte is the main source of the quick elevation of CINC-1 serum levels in the TO-induced acute phase condition namely $2-4 \mathrm{~h}$ after TOinjection of hind limb muscle. Both IL- 6 and IL- $1 \beta$ may be responsible for such upregulation by directly interacting with the hepatocytes.

While recruitment of inflammatory cells was observed in the inflamed muscle, no recruitment of inflammatory cells was seen in the saline-treated muscle, in the noninjured fore limb muscle, liver, lungs, kidneys and spleen of the TO-treated rats. Similar observations were recently published by Renckens et $a .^{55}$ stating that no histopathologic differences were observed between the lungs of mice following turpentine-injection or saline-injection of skeletal muscle.

TO is believed to induce aseptic local abscesses without detectable injury to other tissues. ${ }^{27,28,39,40}$ This is clearly different from agents inducing an acute systemic response, like the administration of bacterial endotoxin (lipopolysaccharide). ${ }^{40}$ Thus, the TO-induced acute-phase response model allows studying the effect of cytokines produced at distant sites on the liver. It reproduces changes observed in human disease states. ${ }^{16-18,20-22}$

The current study suggests that CINC-1 is produced in the liver as an early acute-phase protein well before most of the other classical APPs, such as $\alpha 1$-acid glycoprotein, $\alpha 1$-proteinase inhibitor, and the major rat APP, $\alpha 2$-macroglobulin ${ }^{56}$ and hemeoxygenase- $1{ }^{28}$ The CINC-1 expression in the liver occurred earlier than at the site of injury, and also to a higher extent. A low systemic effect of TO cannot be excluded, however, it is not accompanied by histologically detectable morphological changes in the liver or other organs (Figure 4 and Supplementary material).

At the site of injury a significant increase of the neutrophil elastase positive cells was found after $2 \mathrm{~h}$ TO injection, when the CINC-1 mRNA and protein expression increased as well. The recruitment of neutrophils was maximal $24 \mathrm{~h}$ after TO injection, perhaps explaining the secondary rise in serum creatine kinase at $24 \mathrm{~h}$ (Figure 2a). However the CINC-1 expression had already decreased at this time, suggesting that neutrophil recruitment is not the primary cause of increased CINC-1 induction.

The in vitro experiments demonstrate that CINC-1 expression in hepatocytes is stimulated by acute-phase cytokines, mainly by $\mathrm{IL}-1 \beta$, and to a lesser extent by IL-6 and TNF- $\alpha$. Kinetic experiments have shown that IL- $1 \beta$, IL-6, and to a lesser extent TNF- $\alpha$ also were able to induce detectable increases of CINC-1 gene expression within $20 \mathrm{~min}$ after beginning in vitro stimulation of the hepatocytes (Figure 9). Thus, it is noticeable that IL-6 was detected at the highest serum concentration levels after intramuscular TO injection; its expression was increased in the injured muscle, but not in the liver. An earlier study proved that IL$1 \beta$ and TNF- $\alpha$ but not IL- 6 induce the IL- 8 expression in human hepatocytes. In contrast to our study, the authors did use cell lines and not primary cultures. ${ }^{57}$

As IFN- $\gamma$ is known to induce some chemokines such as monokine induced by gamma interferon (MIG), or gamma-interferon inducible protein (IP10), ${ }^{58}$ we investigated IFN- $\gamma$ gene expression in the liver and injured muscle. In our model, IFN- $\gamma$ serum levels increased with a maximum of $12 \mathrm{~h}$ after the TO-injection, and its expression in the injured muscle also increased with a similar 

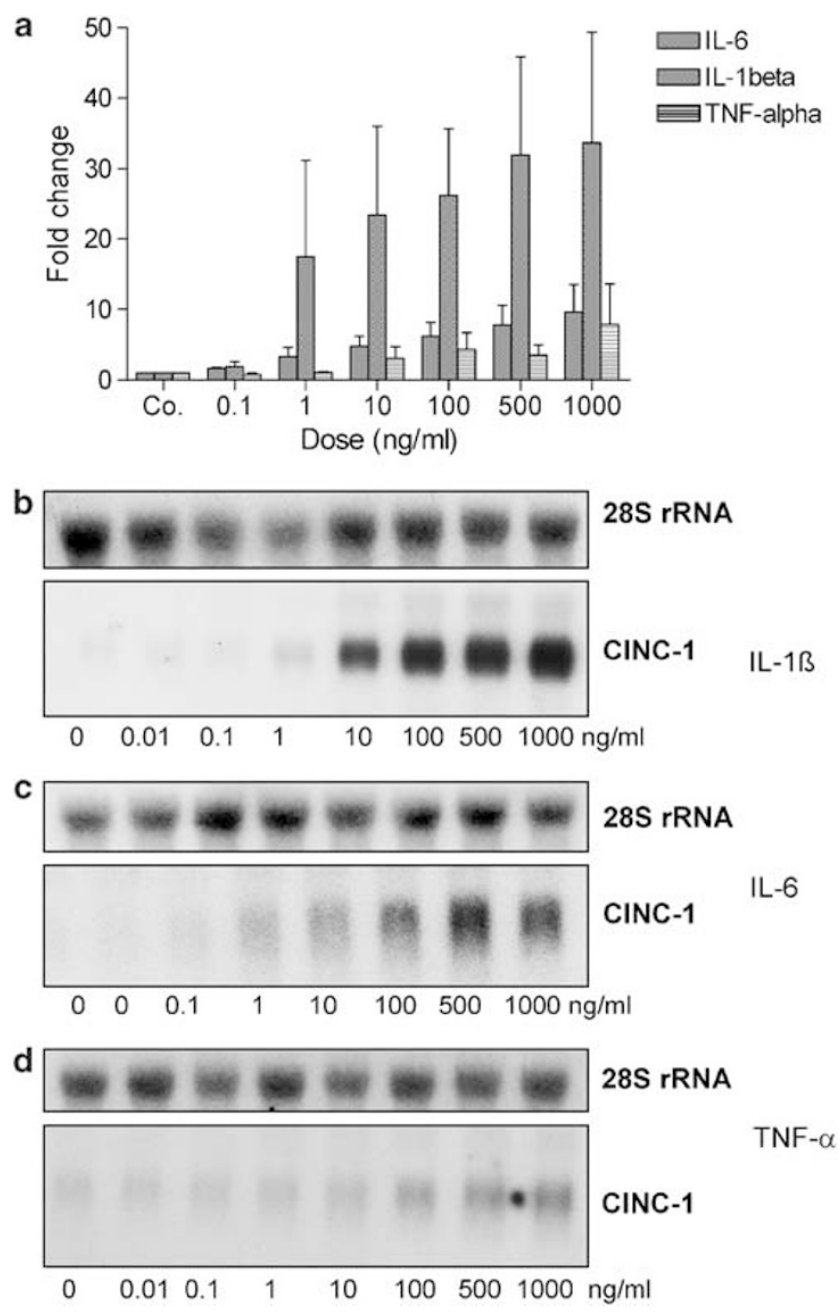

Figure 8 Real-time RT-PCR (a) and Northern blot (b-d) analysis of CINC-1 gene expression in hepatocytes stimulated for $3 \mathrm{~h}$ with increasing doses of acute-phase cytokines. In hepatocytes treated with IL1- $1 \beta$ (a, b) or IL-6 (a, c), the expression levels of CINC-1 reached several-fold increase compared to untreated controls. In contrast, TNF- $\alpha(\mathbf{a}, \mathbf{d})$ used in the high doses only was able to induce CINC-1 mRNA expression in primary hepatocytes, to about two-fold compared to control levels. Results represent mean value \pm s.e.m. of three experiments (a). Northern blot analysis has been performed using pooled RNA from three separate experiments. Control hybridizations were performed using a specific probe for $28 \mathrm{~S}$ rRNA.

time kinetics. Therefore, we also investigated the effect of IFN- $\gamma$ on CINC-1 gene expression in hepatocytes. CINC-1 gene expression was not significantly regulated in primary culture of hepatocytes by IFN- $\gamma$; furthermore, combinations of IFN- $\gamma$ with other cytokines resulted in the effect of the corresponding cytokine without any additional influence of IFN- $\gamma$.

Previously, lower concentrations of CXC-chemokines imparted hepatoprotective effects, whereas high concentrations of chemokines were associated with increased peripheral leukocyte recruitment to the liver. ${ }^{1}$ On the other hand, Bajt et al. ${ }^{59}$ have shown that macrophage inflammatory pro- tein-2 (MIP-2) treatment caused a temporary increase of sinusoidal neutrophil accumulation in $\mathrm{C} 3 \mathrm{Heb} / \mathrm{FeJ}$ mice, while the CXC-chemokine KC (GRO, CINC-1 homologue) was largely ineffective in activating neutrophils or recruiting them into the liver.

In a study by Copple et $a{ }^{31}{ }^{31}$ a pyrrolizidine alkaloid plant toxin, monocrotaline that causes hepatotoxicity in humans and animals was intraperitoneally injected in rats, and produced timedependent hepatic parenchymal cell (HPC) injury, and inflammatory infiltrate consisting of neutrophils (PMNs). PMN accumulation was preceded by upregulation of CINC-1 and MIP-2 in the liver. Interestingly, inhibition of Kupffer cell function with gadolinium chloride significantly reduced CINC-1 protein in the plasma after MCT treatment, but had no effect on hepatic PMN accumulation. Depletion of PMNs prior to MCT treatment reduced hepatic PMN accumulation by $80 \%$, but it had no effect on MCT-induced HPC injury, nor had inhibition of TNF- $\alpha$ synthesis. In the current study, hepatic CINC-1 synthesis is not followed by hepatic inflammatory infiltrate consisting of neutrophils, suggesting that CINC-1 is not sufficient alone to induce the recruitment of inflammatory cells outside of the site of injury, an additional candidate is MIP-2. ${ }^{59}$ These results are further confirmed by the lack of recruitment of inflammatory cells into the liver in the acute-phase model of TO intramuscular injection, as shown in the present work.

On the other hand, the increased CINC-1 serum levels could be related to rapid increase of neutrophil counts in the blood, which might be due to rapid release of young cells from the bone marrow. ${ }^{60}$ The lymphocyte counts showed decrease at the same time (Figure 1) ${ }^{60,61}$ Similarly, in previous reports, significant leukocytosis and neutrophilia, and decrease of circulating lymphocytes, remaining below control levels through several days was observed after subcutaneous and intramuscular TO treatment of rats and dogs. ${ }^{60-62}$

Monocyte chemotactic protein-1 and Gro- $\beta$, CINC1 sequence related human chemokines have been implicated in the mobilization of leukocytes from the bone marrow. ${ }^{63,64}$

In addition to the local chemotactic activity, CINC-1 has mitogenic and antiapoptotic functions, ${ }^{12}$ it promotes the liver cell survival by interfering with the mitochondrial pathway of apoptosis. ${ }^{65}$ This may be the reason why the nature has provided the animal body with this additional defence mechanism, which is activated in case of tissue damage.

In conclusion, CINC-1 is a positive acute phase protein rapidly synthesized in the liver by hepatocytes through the action of acute phase mediators after induction of inflammation at distant sites. Systemic CINC-1 may not only serve to mobilize leukocytes from the bone marrow but it may also have an undefined protective effect in other tissues. 

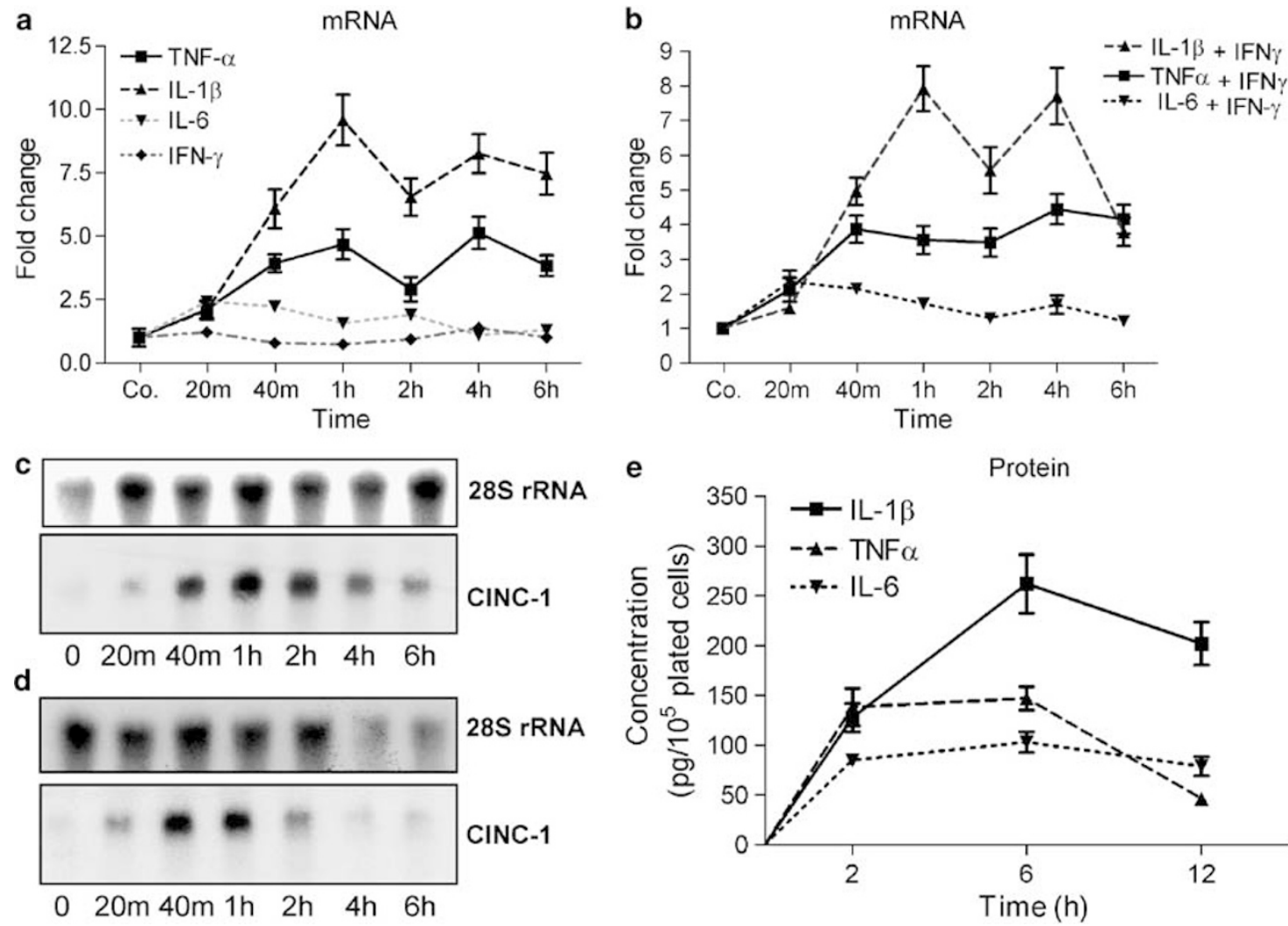

28S rRNA

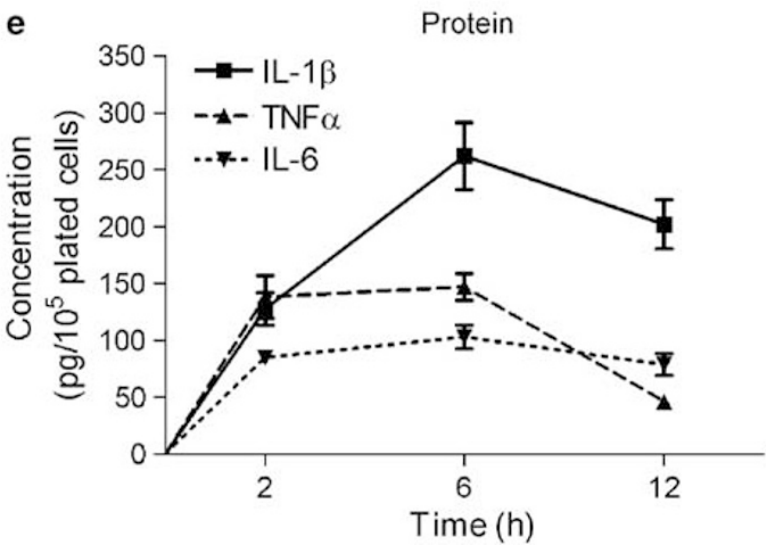

Figure 9 Kinetics of CINC-1 gene expression in hepatocytes stimulated with acute-phase cytokines analyzed with real time RT-PCR (a, b), northern blot (c, d) and ELISA (e). In hepatocytes treated with $500 \mathrm{ng} / \mathrm{ml} \mathrm{IL-1} \mathrm{(a,} \mathrm{c),} \mathrm{IL-6} \mathrm{(a,} \mathrm{d),} \mathrm{TNF-} \beta$ and IFN- $\gamma$, the expression levels of CINC-1 increased compared to untreated controls. The induction was detectable 20 min after the addition of the cytokines to the cells. On the other hand, neither interferon- $\gamma$ alone nor in combination with other cytokines (at concentration of $100 \mathrm{ng} / \mathrm{ml}$ of the used cytokines) induced significant changes in the CINC-1 gene expression (b), when compared to other cytokines alone (a). The mRNA expression patterns in hepatocytes after single cytokine treatments were followed by a similar protein release pattern measured by ELISA in the supernatants of the treated cells (e). Results represent mean value \pm s.e.m. of three experiments (a, b and e). Northern blot analysis has been performed using pooled RNA from three separate experiments. Control hybridizations were performed using a specific probe for 28S rRNA.

Table 3 Comparison of CINC-1 mRNA expression in liver, injured and noninjured muscle, of the turpentine oil acute phase model, in control and IL-6 stimulated hepatocytes (HC), and in Kupffer cells (KC)

CINC-1 Expression

$\operatorname{Exp} \times 10^{-3} \pm$ s.e.m. ${ }^{\mathrm{a}}$ Ct-value

Control liver

Control muscle

Liver max. induction (6h)

Injured muscle max. induction $(6 \mathrm{~h})$

Normal muscle max. induction $(6 \mathrm{~h})$

Control kupffer cells

IL-6-beta max induced KC

Control hepatocytes

IL-6-beta max induced HC

\begin{tabular}{cc}
$2 \pm 0.45$ & 27.64 \\
$0.5 \pm 0.2$ & 31.49 \\
$603 \pm 200$ & 19.32 \\
$94 \pm 22.4$ & 22.57 \\
$3 \pm 0.3$ & 27.99 \\
$121 \pm 2.0$ & 19.15 \\
$88 \pm 0.4$ & 19.42 \\
$5 \pm 1.2$ & 23.07 \\
$17 \pm 0.5$ & 22.01 \\
\hline
\end{tabular}

The expression levels in this table are described by the Ct-values obtained in real time RT-PCR, and by the expression levels normalised with $\beta$-actin as an endogenous control. The basal CINC-1 expression in control liver and muscle was low, and in the liver it was higher than in the muscle. After injection of TO into muscle: CINC-1 expression reached in the liver 6.38 times higher levels than in the muscle, s.e.m. $=$ standard error of measurement. Results represent mean value \pm s.e.m. of three animals.

${ }^{\mathrm{a}}$ During a real-time PCR the number of cycle when gene expression of any specific gene under study reaches a predetermined threshold of detection is known as the 'Ct value'.

\section{Acknowledgements}

We greatly appreciate the helpful work of Sonja Heyroth, Sylvia Bierkamp, Melanie Heinemann, Sandra Georgi and Christine Hoffmann. This work was supported by DFG Grants SFB 402 TP: C6, D3 and GRK 335.

\section{References}

1 Simpson KJ, Henderson NC, Bone-Larson CL, et al. Chemokines in the pathogenesis of liver disease: so many players with poorly defined roles. Clin Sci 2003;104:47-63.

2 Huang YS, Chan CY, Wu JC, et al. Serum levels of interleukin-8 in alcoholic liver disease: relationship with disease stage, biochemical parameters and survival. J Hepatol 1996;24:377-384.

3 Shimoda K, Begum NA, Shibuta K, et al. Interleukin-8 and hIRH (SDF1-alpha/PBSF) mRNA expression and histological activity index in patients with chronic hepatitis C. Hepatology 1998;28:108-115.

4 Maltby J, Wright S, Bird G, et al. Chemokine levels in human liver homogenates: associations between GRO 
alpha and histopathological evidence of alcoholic hepatitis. Hepatology 1996;24:1156-1160.

5 Sheron N, Bird G, Koskinas J, et al. Circulating and tissue levels of the neutrophil chemotaxin interleukin8 are elevated in severe acute alcoholic hepatitis, and tissue levels correlate with neutrophil infiltration. Hepatology 1993;18:41-46.

6 Hill DB, Marsano LS, McClain CJ. Increased plasma interleukin-8 concentrations in alcoholic hepatitis. Hepatology 1993;18:576-580.

7 Thornton AJ, Strieter RM, Lindley I, et al. Cytokineinduced gene expression of a neutrophil chemotactic factor/IL-8 in human hepatocytes. J Immunol 1990; 144:2609-2613.

8 Maher JJ. Rat hepatocytes and Kupffer cells interact to produce interleukin-8 (CINC) in the setting of ethanol. Am J Physiol 1995;269:G518-G523.

9 Rowell DL, Eckmann L, Dwinell MB, et al. Human hepatocytes express an array of proinflammatory cytokines after agonist stimulation or bacterial invasion. Am J Physiol 1997;273:G322-332.

10 Joshi-Barve S, Barve SS, Butt W, et al. Inhibition of proteasome function leads to NF-kappaB-independent IL-8 expression in human hepatocytes. Hepatology 2003;38:1178-1187.

11 Osawa Y, Nagaki M, Banno Y, et al. Tumor necrosis factor alpha-induced interleukin-8 production via NFkappaB and phosphatidylinositol 3-kinase/Akt pathways inhibits cell apoptosis in human hepatocytes. Infect Immun 2002;70:6294-6301.

12 Kaibori M, Yanagida H, Yokoigawa N, et al. Effect of pirfenidone on induction of chemokines in rat hepatocytes. Transplant Proc 2004;36:1980-1984.

13 Kaibori M, Yanagida H, Nakanishi H, et al. Hepatocyte growth factor stimulates the induction of cytokineinduced neutrophil chemoattractant through the activation of NF-kappaB in rat hepatocytes. J Surg Res 2006;130:88-93.

$14 \mathrm{Koj}$ A. Cytokines regulating acute inflammation and synthesis of acute-phase proteins. Blut 1985;51: 267-274.

15 Ramadori G, Christ B. Cytokines and the hepatic acute-phase response. Semin Liver Dis 1999;19: 141-155.

16 Kim YI, Song KE, Ryeon HK, et al. Enhanced inflammatory cytokine production at ischemia/reperfusion in human liver resection. Hepatogastroenterology 2002;49:1077-1082.

17 Basso B, Gimenez F, Lopez C. IL-1, IL-6 and IL-8 levels in gyneco-obstetric infections. Infect Dis Obstet Gynecol 2005;13:207-211.

18 Halter J, Steinberg J, Fink G, et al. Evidence of systemic cytokine release in patients undergoing cardiopulmonary bypass. J Extra Corpor Technol 2005; $37: 272-277$.

19 McClain C, Barve S, Joshi-Barve S, et al. Dysregulated cytokine metabolism, altered hepatic methionine metabolism and proteasome dysfunction in alcoholic liver disease. Alcohol Clin Exp Res 2005;29:180S$188 \mathrm{~S}$.

20 Stoeck K, Bodemer M, Zerr I. Pro- and anti-inflammatory cytokines in the CSF of patients with CreutzfeldtJakob disease. J Neuroimmunol 2006;172:175-181.

21 Bodet C, Chandad F, Grenier D. Porphyromonas gingivalis-induced inflammatory mediator profile in an ex vivo human whole blood model. Clin Exp Immunol 2006;143:50-57.
22 Gabay C, Kushner I. Acute-phase proteins and other systemic responses to inflammation. N Engl J Med 1999;340:448-454.

23 Baggiolini M, Walz A, Kunkel SL. Neutrophil-activating peptide-1/interleukin 8, a novel cytokine that activates neutrophils. J Clin Invest 1989;84:1045-1049.

24 Ramadori G, Sipe JD, Dinarello CA, et al. Pretranslational modulation of acute-phase hepatic protein synthesis by murine recombinant interleukin 1 (IL-1) and purified human IL-1. J Exp Med 1985;162: 930-942.

25 Ramadori G, Van Damme J, Rieder H, et al. Interleukin 6 , the third mediator of acute-phase reaction, modulates hepatic protein synthesis in human and mouse. Comparison with interleukin 1 beta and tumor necrosis factor-alpha. Eur J Immunol 1988;18:1259-1264.

26 Ramadori G, Meyer zum Buschenfelde KH. Acutephase reaction and its mediators. 1: Interleukin-1. Z Gastroenterol 1989;27:746-750.

27 Ramadori G, Meyer zum Buschenfelde KH. The acutephase reaction and its mediators. II: Alpha tumor necrosis factor and interleukin 6. Z Gastroenterol 1990;28:14-21.

28 Tron K, Novosyadlyy R, Dudas J, et al. Upregulation of heme oxygenase-1 gene by turpentine oil-induced localized inflammation: involvement of interleukin-6. Lab Invest 2005;85:376-387.

29 Watanabe K, Konishi K, Fujioka M, et al. The neutrophil chemoattractant produced by the rat kidney epithelioid cell line NRK-52E is a protein related to the KC/gro protein. J Biol Chem 1989;264:19559-19563.

30 Watanabe K, Koizumi F, Kurashige Y, et al. Rat CINC, a member of the interleukin-8 family, is a neutrophilspecific chemoattractant in vivo. Exp Mol Pathol 1991;55:30-37.

31 Copple BL, Ganey PE, Roth RA. Liver inflammation during monocrotaline hepatotoxicity. Toxicology 2003;190:155-169.

32 Handa O, Naito Y, Takagi T, et al. Tumor necrosis factor-\{alpha\}-induced cytokine-induced neutrophil chemoattractant-1 (CINC-1) production by rat gastric epithelial cells: role of reactive oxygen species and nuclear Factor-\{kappa\}B. J Pharmacol Exp Ther 2004; 309:670-676.

33 Calkins CM, Bensard DD, Shames BD, et al. IL-1 regulates in vivo $\mathrm{C}-\mathrm{X}-\mathrm{C}$ chemokine induction and neutrophil sequestration following endotoxemia. J Endotoxin Res 2002;8:59-67.

34 Yamada S, Iida T, Tabata T, et al. Alcoholic fatty liver differentially induces a neutrophil-chemokine and hepatic necrosis after ischemia-reperfusion in rat. Hepatology 2000;32:278-288.

35 Saito JM, Maher JJ. Bile duct ligation in rats induces biliary expression of cytokine- induced neutrophil chemoattractant. Gastroenterology 2000;118:11571168.

36 Takaishi K, Ohtsuka T, Tsuneyoshi S, et al. Inhibition of the production of rat cytokine-induced neutrophil chemoattractant(CINC)-1, a member of the inter leukin-8 family, by adenovirus-mediated overexpression of IkappaBalpha. J Biochem (Tokyo) 2000;127: 511-516.

37 Harada A, Sekido N, Akahoshi T, et al. Essential involvement of interleukin-8 (IL-8) in acute inflammation. J Leukoc Biol 1994;56:559-564.

38 DiSilvestro RA, Marten JT. Effects of inflammation and copper intake on rat liver and erythrocyte $\mathrm{Cu}-\mathrm{Zn}$ 
superoxide dismutase activity levels. J Nutr 1990;120: 1223-1227.

39 Wusteman M, Wight DG, Elia M. Protein metabolism after injury with turpentine: a rat model for clinical trauma. Am J Physiol 1990;259:E763-E769.

40 Boelen A, Kwakkel J, Alkemade A, et al. Induction of type 3 deiodinase activity in inflammatory cells of mice with chronic local inflammation. Endocrinology 2005;146:5128-5134.

41 Bouwens L, Baekeland M, De Zanger R, et al. Quantitation, tissue distribution and proliferation kinetics of Kupffer cells in normal rat liver. Hepatology 1986;6:718-722.

42 Seglen PO. Preparation of rat liver cells. I. Effect of Ca $2+$ on enzymatic dispersion of isolated, perfused liver. Exp Cell Res 1972;74:450-454.

43 Seglen PO. Preparation of rat liver cells. 3. Enzymatic requirements for tissue dispersion. Exp Cell Res 1973;82:391-398.

44 Haralanova-Ilieva B, Ramadori G, Armbrust T. Expression of osteoactivin in rat and human liver and isolated rat liver cells. J Hepatol 2005;42:565-572.

45 Knittel T, Fellmer P, Neubauer K, et al. The complement-activating protease $\mathrm{P} 100$ is expressed by hepatocytes and is induced by IL-6 in vitro and during the acute-phase reaction in vivo. Lab Invest 1997;77: 221-230.

46 Neubauer K, Baruch Y, Lindhorst A, et al. Gelsolin gene expression is upregulated in damaged rat and human livers within non-parenchymal cells and not in hepatocytes. Histochem Cell Biol 2003;120:265-275.

47 Scharf J, Ramadori G, Braulke T, et al. Synthesis of insulin-like growth factor binding proteins and of the acid-labile subunit in primary cultures of rat hepatocytes, of Kupffer cells, and in cocultures: regulation by insulin, insulinlike growth factor, and growth hormone. Hepatology 1996;23:818-827.

48 Armbrust $\mathrm{T}$, Nordmann B, Kreissig M, et al. C1Q synthesis by tissue mononuclear phagocytes from normal and from damaged rat liver: up-regulation by dexamethasone, down-regulation by interferon gamma, and lipopolysaccharide. Hepatology 1997;26: 98-106.

49 Chirgwin JM, Przybyla AE, MacDonald RJ, et al. Isolation of biologically active ribonucleic acid from sources enriched in ribonuclease. Biochemistry 1979; 18:5294-5299.

50 Huang Z, Fasco MJ, Kaminsky LS. Optimization of Dnase I removal of contaminating DNA from RNA for use in quantitative RNA-PCR. Biotechniques 1996;20: 1012-1020.

51 Gibson UE, Heid CA, Williams PM. A novel method for real time quantitative RT-PCR. Genome Res 1996;6: 995-1001.

52 Alwine JC, Kemp DJ, Parker BA, et al. Detection of specific RNAs or specific fragments of DNA by fractionation in gels and transfer to diazobenzyloxymethyl paper. Methods Enzymol 1979;68:220-242.
53 Woo TH, Patel BK, Cinco M, et al. Real-time homogeneous assay of rapid cycle polymerase chain reaction product for identification of Leptonema illini. Anal Biochem 1998;259:112-117.

54 Dudas J, Papoutsi M, Hecht M, et al. The homeobox transcription factor Prox1 is highly conserved in embryonic hepatoblasts and in adult and transformed hepatocytes, but is absent from bile duct epithelium. Anat Embryol 2004;208:359-366.

55 Renckens R, Roelofs JJ, Knapp S, et al. The acute-phase response and serum amyloid a inhibit the inflammatory response to Acinetobacter baumannii Pneumonia. J Infect Dis 2006;193:187-195.

56 Schreiber G, Tsykin A, Aldred AR, et al. The acutephase response in the rodent. Ann NY Acad Sci 1989;557:61-85.

57 Thornton AJ, Ham J, Kunkel SL. Kupffer cell-derived cytokines induce the synthesis of a leukocyte chemotactic peptide, interleukin-8, in human hepatoma and primary hepatocyte cultures. Hepatology 1991;14: 1112-1122.

58 Ren X, Kennedy A, Colletti LM. CXC chemokine expression after stimulation with interferon-gamma in primary rat hepatocytes in culture. Shock 2002; 17:513-520.

59 Bajt ML, Farhood A, Jaeschke H. Effects of CXC chemokines on neutrophil activation and sequestration in hepatic vasculature. Am J Physiol Gastrointest Liver Physiol 2001;281:G1188-G1195.

60 Williams DM, Johnson NW. Alterations in peripheral blood leucocyte distribution in response to local inflammatory stimuli in the rat. J Pathol 1976;118: 129-141.

61 Williams DM, Johnson NW. Early colonisation of a local inflammatory lesion and its relationship to changes in systemic leucocyte availability: a study of turpentine-induced lesions in the rat. J Pathol 1978; 125:139-149.

62 Gossett KA, MacWilliams PS, Cleghorn B. Sequential morphological and quantitative changes in blood and bone marrow neutrophils in dogs with acute inflammation. Can J Comp Med 1985;49:291-297.

$63 \mathrm{Xu}$ YX, Talati BR, Janakiraman N, et al. Growth factors: production of monocyte chemotactic protein-1 (MCP1/JE) by bone marrow stromal cells: effect on the migration and proliferation of hematopoietic progenitor cells. Hematology 1999;4:345-356.

64 King AG, Horowitz D, Dillon SB, et al. Rapid mobilization of murine hematopoietic stem cells with enhanced engraftment properties and evaluation of hematopoietic progenitor cell mobilization in rhesus monkeys by a single injection of SB-251353, a specific truncated form of the human CXC chemokine GRObeta. Blood 2001;97:1534-1542.

65 Hanson JC, Bostick MK, Campe CB, et al. Transgenic overexpression of interleukin-8 in mouse liver protects against galactosamine/endotoxin toxicity. J Hepatol 2006;44:359-367.

Supplementary Information accompanies the paper on the Laboratory Investigation website (http:// www.nature.com/labinvest) 